\title{
The Spectrum of Fungal Allergy
}

\author{
Birgit Simon-Nobbe Ursula Denk Verena Pöll Raphaela Rid \\ Michael Breitenbach \\ Department of Cell Biology, University of Salzburg, Salzburg, Austria
}

\section{Key Words}

Allergy $\cdot$ Cross-reactivity $\cdot$ Epitope $\cdot$ Fungi $\cdot \operatorname{lgE} \cdot$ Mold $\cdot$

Recombinant allergen

\begin{abstract}
Fungi can be found throughout the world. They may live as saprophytes, parasites or symbionts of animals and plants in indoor as well as outdoor environment. For decades, fungi belonging to the ascomycota as well as to the basidiomycota have been known to cause a broad panel of human disorders. In contrast to pollen, fungal spores and/or mycelial cells may not only cause type I allergy, the most prevalent disease caused by molds, but also a large number of other illnesses, including allergic bronchopulmonary mycoses, allergic sinusitis, hypersensitivity pneumonitis and atopic dermatitis; and, again in contrast to pollen-derived allergies, fungal allergies are frequently linked with allergic asthma. Sensitization to molds has been reported in up to $80 \%$ of asthmatic patients. Although research on fungal allergies
\end{abstract}

$\mathrm{ABPA}=$ Allergic bronchopulmonary aspergillosis; $\mathrm{ABPM}=$ allergic bronchopulmonary mycosis; $A D$ = atopic dermatitis; GST = glutathione-S-transferase; $\mathrm{HSP}=$ heat shock protein; $\mathrm{MnSOD}=$ manganesedependent superoxide dismutase; RAST $=$ radioallergosorbent test ${ }_{i}$ SPT $=$ skin prick test.

\section{KARGER \\ Fax +41613061234 E-Mail karger@karger.ch} www.karger.com dates back to the 19th century, major improvements in the diagnosis and therapy of mold allergy have been hampered by the fact that fungal extracts are highly variable in their protein composition due to strain variabilities, batch-tobatch variations, and by the fact that extracts may be prepared from spores and/or mycelial cells. Nonetheless, about 150 individual fungal allergens from approximately 80 mold genera have been identified in the last 20 years. First clinical studies with recombinant mold allergens have demonstrated their potency in clinical diagnosis. This review aims to give an overview of the biology of molds and diseases caused by molds in humans, as well as a detailed summary of the latest results on recombinant fungal allergens.

Copyright $\odot 2007$ S. Karger AG, Basel

\section{Introduction}

Fungi are eukaryotic, non-chlorophyllous and heterotrophic organisms that depend on external nutrients and therefore live as saprophytes, parasites or symbionts of animals and plants under nearly all environmental conditions. The phenotype of molds ranges from a unicellular to a dimorphic or filamentous appearance. Out of over 100,000 fungal species reported, a few hundred occur as opportunists and about 100 are known to elicit mycoses in man and animals [1]. More than 80 mold genera have

Correspondence to: Dr. Birgit Simon-Nobbe

Department of Cell Biology, Division Genetics

University of Salzburg, Hellbrunnerstrasse 34

AT-5020 Salzburg (Austria)

Tel. +43662 8044 5791, Fax +43 6628044 144, E-Mail birgit.simon@sbg.ac.at 
been shown to induce type I allergies in susceptible persons, whereas allergenic proteins have been identified in 23 fungal genera.

For decades, fungal spores and mycelial cells have been known to be a major health risk. In contrast to airborne pollen, fungal spores are not primarily associated with IgE-mediated type I allergies but also with a broad panel of other diseases, e.g. life-threatening primary and secondary infections in immunocompromised patients. Additionally, molds have been described to cause allergic bronchopulmonary mycosis (ABPM) and hypersensitivity pneumonitis, fungal sinusitis and toxic pneumonia, and a large number of mycotoxins have been listed $[2,3]$. The broad panel of diseases results from the inhalation and ingestion of fungal spores and vegetative cells (hyphae) or the contact with fungal cells. In contrast to other allergenic sources, fungi are very common in the environment, and exposure to airborne spores is almost constant throughout the year. A major difference to other sources, e.g. house dust mite or pollen, is that fungi may colonize the human body, and they may damage airways by the production of toxins, proteases, enzymes [4] and volatile organic compounds [5]. Thus, molds have a far greater impact on the patients' immune system than pollen or other allergenic sources.

\section{Biology of Molds}

Fungi are eukaryotic, filamentous and mostly sporebearing organisms representing a separate entity within living organisms. In general, a sexual generation is followed by an asexual generation during a life cycle. Each of these generations may propagate independently, exhibiting different morphologies (pleomorphism). The broad majority of allergy-causing molds belong to the divisions of ascomycota or basidiomycota. Ascomycota produce their ascospores in the course of sexual reproduction in the ascus, whereas basidiomycota produce their meiospores or basidiospores, respectively, in the basidium. About 30,000 species of ascomycota and 25,000 species of basidiomycota have been described. The size of fungal spores ranges from 2-3 $\mu \mathrm{m}$ (Cladosporium, Aspergillus and Penicillium) up to $160 \mu \mathrm{m}$ (Helminthosporium). The average size lies between 2 and $10 \mu \mathrm{m}$, but spores of $500 \mu \mathrm{m}$ (Alternaria longissima) [6] have also been found.

Although optimal growth conditions vary among molds, their optimal growth temperature ranges from 18 to $32^{\circ} \mathrm{C}$. For growth, they require oxygen, water and a carbohydrate source. Molds occur in outdoor and indoor environments, and they grow on virtually any substrate, including glass and plastic surfaces.

The outdoor spore concentration ranges from 230 to $10^{6}$ spores $/ \mathrm{m}^{3}[7,8]$. Atmospheric fungal spore concentration exceeds mean pollen concentration 100-1,000 times [9]. Spore concentration in the air varies substantially depending on climatic factors such as temperature, wind and moisture. The majority of the fungal species grow in the outdoor environment. Examples are Alternaria, Cladosporium, Epicoccum and Ganoderma.

Indoor fungi are a mixture of those growing indoors and those that have entered from outdoors [10]. Their incidence is influenced by humidity, ventilation, the content of biologically degradable material, and the presence of pets, plants and carpets [11]. In general, indoor spore concentration is less than half of the outdoor count (unless there is indoor mold growth) varying from 100 to 1,000 spores $/ \mathrm{m}^{3}[10,12]$. In a Danish study on 23 moldinfected buildings, the most frequent mold genera encountered were Penicillium (68\%) and Aspergillus (56\%), followed by Chaetomium, Ulocladium, Stachybotrys and Cladosporium (ranging from 22 to 15\%) [13].

\section{Fungal Type II, III and IV Allergies}

The immunological mechanisms underlying mold allergies are hypersensitivity reactions of types I, II, III and IV. The spectrum of allergic symptoms caused by these hypersensitivity reactions is very broad, including rhinitis, asthma, atopic dermatitis (AD) and ABPM. Since this review has its main focus on IgE-mediated type I allergies, only a short overview about allergic diseases of types II, III and IV is given.

\section{Clinical Manifestations of Fungal Type II, III and IV Allergies}

\section{Allergic Bronchopulmonary Mycoses}

Most frequently, ABPM is caused by Aspergillus fumigatus, which may grow in the bronchial lumen, leading to a persistent bronchial inflammation inducing bronchiectasis in asthmatic patients. Seven to $22 \%$ of asthmatic patients suffer from allergic bronchopulmonary aspergillosis (ABPA) [14]. Besides A. fumigatus, ABPM is induced by Candida albicans, Curvularia, Geotrichum and Helminthosporium [14]. Allergic reactions involved include types I, III and IV. 


\section{Allergic Sinusitis}

Molds (e.g. Aspergillus, Curvularia, Alternaria and Bipolaris) may cause allergic sinusitis and fungal ball production in the patients' sinuses [15]. In case of allergic sinusitis, multiple sinuses are affected, whereas tissue invasion does not occur. In the patients' mucus, fungal hyphae are detectable. Additionally, patients may show a cutaneous hypersensitivity to specific allergens along with specific IgE and IgG antibodies and an elevated total IgE level [14]. Immunologically, allergic sinusitis is a type I-, III- and IV-mediated allergic reaction.

\section{Hypersensitivity Pneumonitis}

Hypersensitivity pneumonitis (also known as extrinsic allergic alveolitis) is based on type III/IV allergic reactions to repeated inhalation of allergens and may lead to a chronic disease with irreversible lung damage. It is characterized by the presence of precipitating antibodies and an antigen-induced lymphocyte stimulation. The following molds have been associated with hypersensitivity pneumonitis: Aspergillus and Penicillium species, and the basidiomycetes Lentinus edodes, Merulius lacrymans and P. ostreatus $[16,17]$.

Molds not only cause various allergic reactions but they may also produce mycotoxins which affect the immune system.

\section{Mycotoxins}

Mycotoxins - non-volatile, secondary metabolites of low molecular weight produced by fungi - impair the immune system and have neurotoxic, mutagenic, carcinogenic and teratogenic effects. Diseases caused by mycotoxins are called mycotoxicoses. The severity of toxic effects depends on the type of mycotoxin, the duration and dose of exposure and the age, health and nutritional status of the individual affected. Mycotoxins may occur in spores, mycelia, and the matrix in which fungi grow. They are a health risk for farm workers, for persons living in houses with excessive mold growth and for persons exposed to moldy material at the workplace. So far, approximately 300 mycotoxins have been identified. Chronic exposure to mycotoxins causes immunosuppression of varying extent. Prominent examples for mycotoxins are aflatoxin (Aspergillus flavus and A. parasiticus), ergot alkaloids (Claviceps spp., A. fumigatus and Penicillium chermesinum), ochratoxins (A. ochraceus, A. alliaceus, $A$. terreus, $P$. niger and $P$. viridicatum) and trichothecenes (Fusarium sporotrichioides, Microdochium nivale and Stachybotrys atra) $[18,19]$.

\section{Fungal Type I Allergy}

Type I allergy is induced by a large number of fungal genera. The majority of them are members of the ascomycota or the basidiomycota. The most important allergy-causing fungal genera belonging to the ascomycota are Alternaria, Aspergillus, Bipolaris, Candida, Cladosporium, Epicoccum and Phoma, whereas Calvatia, Coprinus, Ganoderma, Pleurotus and Psilocybe are the most prominent genera of the basidiomycota (table 1). In table 1, all allergy-causing fungal genera belonging to the ascomycota, the basidiomycota and the zygomycota along with their prevalence reported in the literature are listed.

The incidence of mold allergy ranges from 6 [20] to $24 \%$ [21] in the general population, up to $44 \%$ among atopics [22] and $80 \%$ among asthmatics [23]. The incidence of mold allergy within asthmatic children is $45 \%$ whereas it is $70 \%$ in asthmatic adults [24].

A high proportion of mold-allergic patients is polysensitized with specific IgE reactivity to various mold, pollen and even food allergens [10,25].

\section{Clinical Manifestations of Fungal Type I Allergy}

\section{Allergic Rhinitis}

Allergic rhinitis is characterized by sneezing, rhinorrhea, pruritus and nasal obstructions. It is induced by a large number of fungal species, with Alternaria, Aspergillus, Bipolaris, Cladosporium, Curvularia and Penicillium being the most prominent.

\section{Allergic Asthma}

Comparing the size of pollen grains and fungal spores, it is obvious that fungal spores are smaller in general. Therefore, they may reach the alveolar surface of the lung inducing chronic inflammation of the lung tissue [26, 27].

In many studies, an apparent link between asthma and fungal sensitization was described [28]. In children, fungal allergy was shown to be associated with increased bronchial reactivity [29-31], whereas in adults severe asthma, intensive care unit admission and even death was observed [32, 33]. In an US study performed in asthmatic patients, up to $80 \%$ of the subjects showed sensitization to molds [23]. In a study on 9814 -year-old children from the Isle of Wight (UK), asthma was the most common disease in children sensitized to molds [20]. Reed [34] stated that fungi have been considered an important 
cause of asthma for more than 60 years. In a Canadian study dealing with 'thunderstorm asthma', high spore (but not pollen) counts in the course of thunderstorms were strongly correlated with asthma exacerbations [35]. Additionally, a strong association between fungal sensitivity, exposure to fungal spores and life-threatening asthmatic episodes was described $[28,36]$. Taken together, the molds Alternaria, Aspergillus, Cladosporium, Helminthosporium, Epicoccum, Aureobasidium and Penicillium have frequently been implicated in allergic asthma [27, 37-39].

\section{Atopic Dermatitis}

$\mathrm{AD}$ is a chronic inflammatory disease of the skin that is associated with high levels of total and allergen-specific IgE [40].

In recent years, Malassezia furfur has been implicated in the pathogenesis of $\mathrm{AD}$ whereas $40-65 \%$ of $\mathrm{AD}$ patients either have a positive skin test, atopy patch test or radioallergosorbent test (RAST) with $M$. furfur extract [41]. Sensitization to Malassezia allergens may be favored by impaired epidermal barriers, increased T-cell reactivity and distinctive features of antigen-presenting cells [42, 43]. Manganese-dependent superoxide dismutase (MnSOD) may be involved as an autoallergen in the pathogenesis of $\mathrm{AD} ; 36 \%$ of patients with a positive $M a$ lassezia sympodialis skin test $(\mathrm{n}=69)$ react with fungal and human MnSOD [44].

Saccharomyces cerevisiae is another yeast species showing a significant correlation between a positive skin prick test (SPT) and $\mathrm{AD}[45]$.

\section{Fungal Allergens}

\section{Allergens from the Ascomycota}

\section{Alternaria alternata}

Among molds associated with allergic disorders, A. alternata is one of the most frequently encountered species, predominantly occurring in the outdoor environment. The incidence of $A$. alternata sensitization within atopics varies between 3.6 and $39.4 \%$ (table 1) depending on the climatic zone and the population tested.

Mari et al. [46] showed that in a cohort of 4,962 patients with respiratory symptoms, $65 \%$ were SPT positive to at least one allergenic source, and 19\% of these allergics reacted to at least one fungal extract, whereas the incidence of sensitization to A. alternata was $66 \%$. Interestingly, within the group of patients being sensitized to a single fungal species, Alternaria, Candida and Trichophyton were the most common.

In several studies, a strong association between an $A$. alternata sensitization and asthma severity was demonstrated $[26,27,29,31,37,38,47]$. In a cross-sectional study by Zureik et al. [26], asthma severity was not associated with sensitization to pollen and cats. According to a study by Halonen et al. [29], Alternaria sensitization at the age of 6 and 11 years, respectively, resulted in a statistically significantly increased risk to develop asthma in childhood. In a large scale study performed in the United States, $38.3 \%$ of 1,286 asthmatic children had positive skin test responses to Alternaria species [47].

Before 1990, little was known about the relevant allergens of A. alternata. Meanwhile 13 allergens of $A$. alternata have been identified (table 2). Most of these allergens are intracellular housekeeping proteins. Nine of these allergens, e.g. NADP-dependent mannitol dehy-

Table 1. Molds inducing type I allergy

\begin{tabular}{|c|c|c|}
\hline & Prevalence, $\%$ & \\
\hline & total population & atopics \\
\hline $\begin{array}{l}\text { ASCOMYCOTA } \\
\text { Pezizomycota }\end{array}$ & & \\
\hline Acremonium (Cephalosporium) & & $16^{\mathrm{a}}[267]$ \\
\hline Alternaria & $3.6-5.5[20,180]$ & $66.1^{\mathrm{b}}[46]$ \\
\hline & $12.6[46]$ & $39.4[22]$ \\
\hline & & $14.6^{\mathrm{c}}[179]$ \\
\hline & & $13.5^{\mathrm{c}}[183]$ \\
\hline & & $\begin{array}{l}3-14.6[181, \\
182]\end{array}$ \\
\hline Aspergillus & $2.4[46]$ & $27.6[22]$ \\
\hline & & $21.3^{\mathrm{c}}[179]$ \\
\hline & & $15[182]$ \\
\hline & & $5^{c}[183]$ \\
\hline Aureobasidium & & $20.5^{\mathrm{d}}[22]$ \\
\hline Bipolaris & & $36.8[22]$ \\
\hline (Drechslera, Helminthosporium) & & $18.8^{\mathrm{c}}[179]$ \\
\hline Botrytis & & $28.2^{\mathrm{d}}[22]$ \\
\hline Chaetomium & & $7.4[268]$ \\
\hline Chrysosporium & & \\
\hline Cladosporium & $2.5[46]$ & $\begin{array}{l}3-18.2[181, \\
182]\end{array}$ \\
\hline & $2.9[20]$ & $15.9^{\mathrm{c}}[179]$ \\
\hline & & $7.4^{\mathrm{c}}[183]$ \\
\hline Claviceps & & \\
\hline Curvularia & & $18.4[22]$ \\
\hline & & $28[184]$ \\
\hline Cylindrocarpon & & \\
\hline
\end{tabular}


Table 1 (continued)

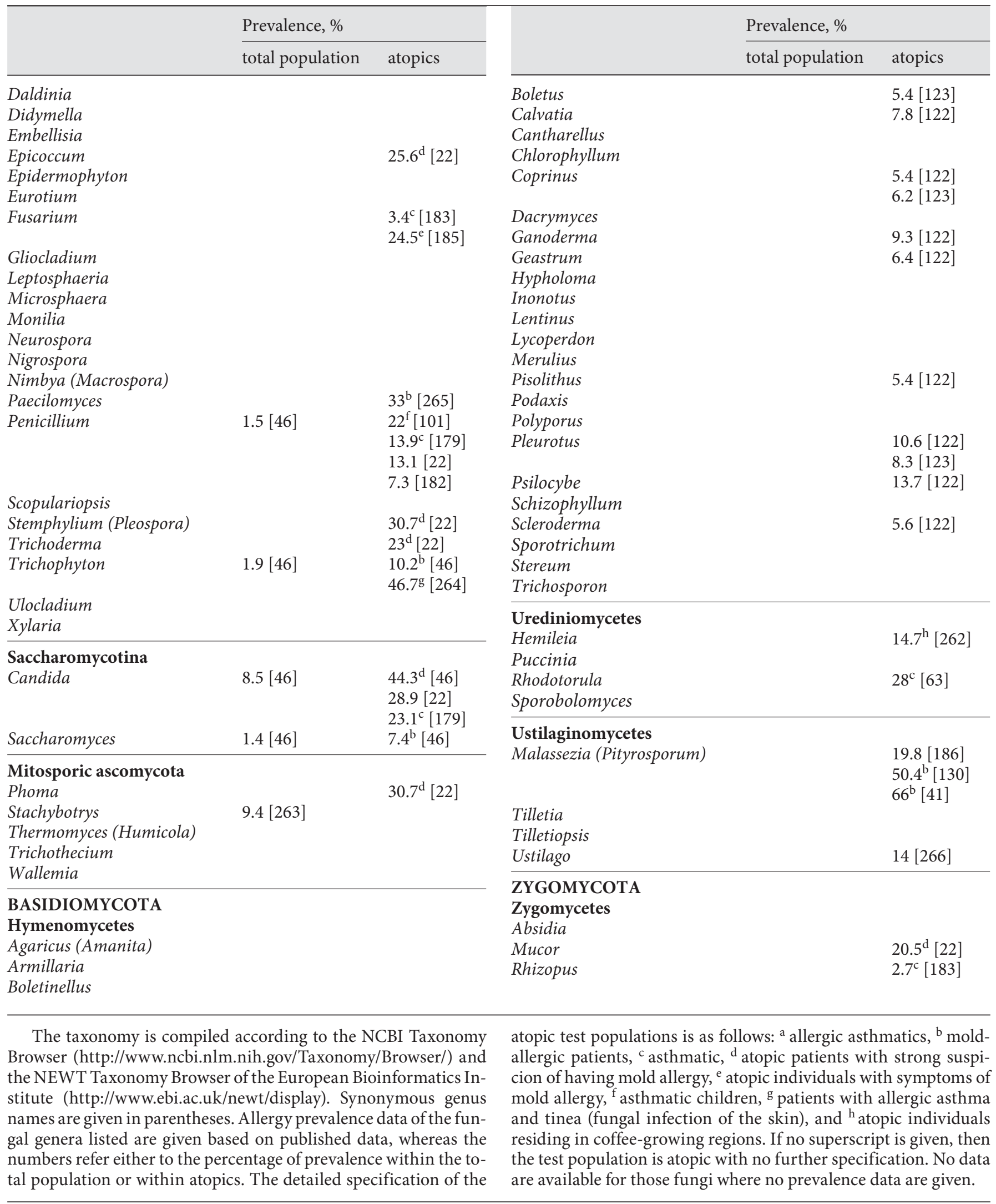


Table 2. List of fungal allergens

\begin{tabular}{|c|c|c|c|c|c|c|c|}
\hline Species & Allergen & $\begin{array}{l}\text { Prevalence } \\
\%\end{array}$ & Biochemical name & RA & $\begin{array}{l}\text { MW } \\
\mathrm{kDa}\end{array}$ & $\begin{array}{l}\text { GenBank } \\
\text { Accession No. }\end{array}$ & Ref. \\
\hline \multicolumn{8}{|l|}{ ASCOMYCOTA } \\
\hline \multirow[t]{18}{*}{ Alternaria alternata } & Alt a 1 & $93^{\mathrm{a}}(\mathrm{n}=43)[171]$ & & + & 28 & U82633 & [164] \\
\hline & & $47^{\mathrm{b}}(\mathrm{n}=19)[171]$ & & & & & \\
\hline & & $98(\mathrm{n}=42)[54]$ & & & & & \\
\hline & Alt a 2 & $0(\mathrm{n}=42)[54]$ & & + & 25 & U62442 & {$[59]$} \\
\hline & & $61(\mathrm{n}=26)[59]$ & & & & & \\
\hline & Alt a 3 & & HSP70 & & 70 & U87807, & {$[56]$} \\
\hline & & & & & & U87808 & \\
\hline & Alt a 4 & & protein disulfide isomerase & & 57 & X84217 & {$[48]$} \\
\hline & Alt a 5 & & acid ribosomal protein $\mathrm{P} 2$ & + & 11 & X78222, & {$[48]$} \\
\hline & Alt a 6 & $21.7(\mathrm{n}=42)[52]$ & enolase & + & 45 & U82437 & [52] \\
\hline & & $15(\mathrm{n}=42)[54]$ & & & & & \\
\hline & Alt a 7 & & flavodoxin (YCP4 homologue) & + & 22 & X78225 & {$[48]$} \\
\hline & Alt a 8 & $41(\mathrm{n}=22)[50]$ & mannitol dehydrogenase & + & 29 & AY191815 & {$[50]$} \\
\hline & Alt a 10 & & aldehyde dehydrogenase & + & 53 & $\begin{array}{l}\text { X78227, } \\
\text { P42041 }\end{array}$ & {$[48]$} \\
\hline & Alt a 12 & & acid ribosomal protein $\mathrm{P} 1$ & + & 11 & X84216 & [48] \\
\hline & Alt a 13 & $82(\mathrm{n}=17)[187]$ & GST & + & 26 & AY514673 & [187] \\
\hline & Alt a $70 \mathrm{kDa}$ & & & & 70 & & [188] \\
\hline & Alt a NTF2 & & nuclear transport factor 2 & + & 13.7 & AJ493280 & [189] \\
\hline Alternaria argyranthemi & Alt $\arg 1$ & & Alt a 1 related & & & AY563280 & [190] \\
\hline Alternaria brassicicola & Alt b 1 & & Alt a 1 related & & & AF499002 & [191] \\
\hline Alternaria blumeae & Alt bl 1 & & Alt a 1 related & & & AY563291 & [190] \\
\hline Alternaria brassicae & Alt br 1 & & Alt a 1 related & & & AY563309 & [190] \\
\hline Alternaria capsici & Alt c 1 & & Alt a 1 related & & & AY563298 & [190] \\
\hline Alternaria carotiincultae & Alt ca 1 & & Alt a 1 related & & & AY563287 & [190] \\
\hline Alternaria cetera & Alt ce 1 & & Alt a 1 related & & & AY563278 & [190] \\
\hline Alternaria cheiranthi & Alt ch 1 & & Alt a 1 related & & & AY563290 & [190] \\
\hline Alternaria cinerariae & Alt ci 1 & & Alt a 1 related & & & AY563308 & [190] \\
\hline Alternaria conjuncta & Alt co 1 & & Alt a 1 related & & & AY563281 & [190] \\
\hline Alternaria crassa & Alt cr 1 & & Alt a 1 related & & & AY563293 & [190] \\
\hline Alternaria cucumerina & Alt cu 1 & & Alt a 1 related & & & AY563300 & [190] \\
\hline Alternaria dauci & Alt d 1 & & Alt a 1 related & & & AY563292 & [190] \\
\hline Alternaria dumosa & Alt du 1 & & Alt a 1 related & & & AY563305 & [190] \\
\hline Alternaria eryngii & Alt e 1 & & Alt a 1 related & & & AY563313 & [190] \\
\hline Alternaria ethzedia & Alt et 1 & & Alt a 1 related & & & AY563284 & [190] \\
\hline Alternaria euphorbiicola & Alt eu 1 & & Alt a 1 related & & & AY563314 & [190] \\
\hline Alternaria japonica & Alt j 1 & & Alt a 1 related & & & AY563312 & [190] \\
\hline Alternaria limoniasperae & Alt 11 & & Alt a 1 related & & & AY563306 & [190] \\
\hline Alternaria longipes & Alt lo 1 & & Alt a 1 related & & & AY563304 & [190] \\
\hline Alternaria macrospora & Alt m 1 & & Alt a 1 related & & & AY563294 & [190] \\
\hline Alternaria metachromatica & Alt me 1 & & Alt a 1 related & & & AY563285 & [190] \\
\hline Alternaria mimicula & Alt mi 1 & & Alt a 1 related & & & AY563310 & [190] \\
\hline Alternaria mouchaccae & Alt mo 1 & & Alt a 1 related & & & AY563279 & [190] \\
\hline Alternaria oregonensis & Alt o 1 & & Alt a 1 related & & & AY563279 & [190] \\
\hline Alternaria petroselini & Alt p 1 & & Alt a 1 related & & & AY563288 & [190] \\
\hline Alternaria photistica & Alt ph 1 & & Alt a 1 related & & & AY563282 & [190] \\
\hline Alternaria porri & Alt po 1 & & Alt a 1 related & & & AY563296 & [190] \\
\hline Alternaria pseudorostrata & Alt ps 1 & & Alt a 1 related & & & AY563295 & [190] \\
\hline Alternaria radicina & Alt $\mathrm{r} 1$ & & Alt a 1 related & & & AY563286 & [190] \\
\hline Alternaria solani & Alt s 1 & & Alt a 1 related & & & AY563299 & [190] \\
\hline Alternaria smyrnii & Alt sm 1 & & Alt a 1 related & & & AY563289 & [190] \\
\hline Alternaria sonchi & Alt so 1 & & Alt a 1 related & & & AY563307 & [190] \\
\hline Alternaria tagetica & Alt t 1 & & Alt a 1 related & & & AY563297 & [190] \\
\hline Alternaria tenuissima & Alt te 1 & & Alt a 1 related & & & AY563302 & [190] \\
\hline
\end{tabular}


Table 2 (continued)

\begin{tabular}{|c|c|c|c|c|c|c|c|}
\hline Species & Allergen & $\begin{array}{l}\text { Prevalence } \\
\%\end{array}$ & Biochemical name & RA & $\begin{array}{l}\mathrm{MW} \\
\mathrm{kDa}\end{array}$ & $\begin{array}{l}\text { GenBank } \\
\text { Accession No. }\end{array}$ & Ref. \\
\hline \multirow[t]{2}{*}{ Aspergillus flavus } & Asp fl 13 & $64^{\mathrm{a}}(\mathrm{n}=14)[192]$ & alkaline serine protease & + & 34 & AF137272 & $\begin{array}{l}{[192,} \\
193]\end{array}$ \\
\hline & Asp fl 18 & & vacuolar serine protease & & & & [194] \\
\hline \multirow[t]{39}{*}{ Aspergillus fumigatus } & Asp f 1 & $100^{\mathrm{e}}(\mathrm{n}=20)[195]$ & ribonuclease & + & 18 & M83781, & {$[71$} \\
\hline & & $\begin{array}{l}75^{\mathrm{g}}(\mathrm{n}=24)[90] \\
60^{\mathrm{f}}(\mathrm{n}=20)[195] \\
46^{\mathrm{c}}(\mathrm{n}=20)[73]\end{array}$ & & & & S39330 & 196] \\
\hline & Asp f 2 & $87^{g}(\mathrm{n}=24)[90]$ & fibrinogen binding protein & + & 37 & U56938 & {$[72]$} \\
\hline & Asp f 3 & $100^{c}(\mathrm{n}=11)[85]$ & peroxisomal membrane protein & + & 19 & U20722 & {$[84$} \\
\hline & & $100^{\mathrm{d}}(\mathrm{n}=20)[195]$ & & & & & $85]$ \\
\hline & & $90^{\mathrm{f}}(\mathrm{n}=20)[195]$ & & & & & \\
\hline & & $62.5^{\mathrm{d}}(\mathrm{n}=8)[85]$ & & & & & \\
\hline & & $32^{\mathrm{d}}(\mathrm{n}=16)[90]$ & & & & & \\
\hline & Asp f 4 & $80^{\mathrm{e}}(\mathrm{n}=20)[195]$ & & + & 30 & AJ001732 & {$[70]$} \\
\hline & & $77^{\mathrm{g}}(\mathrm{n}=24)[90]$ & & & & & \\
\hline & & $\begin{array}{r}0^{\mathrm{t}}(\mathrm{n}=20)[195] \\
74^{\mathrm{c}}(\mathrm{n}-35)\end{array}$ & & & & & \\
\hline & Asp f 5 & $\begin{array}{l}74^{\mathrm{c}}(\mathrm{n}=35)[73] \\
92.6^{\mathrm{c}}(\mathrm{n}=54)[73]\end{array}$ & metalloprotease & + & 40 & Z30424 & [197] \\
\hline & Asp f 6 & $70^{\mathrm{e}}(\mathrm{n}=20)[195]$ & MnSOD & + & 26.5 & U53561 & {$[88]$} \\
\hline & & $63^{\mathrm{g}}(\mathrm{n}=24)[90]$ & & & & & \\
\hline & & $56^{\mathrm{d}}(\mathrm{n}=54)[73]$ & & & & & \\
\hline & & $0^{c}(\mathrm{n}=35)[73]$ & & & & & \\
\hline & & $0^{\mathrm{f}}(\mathrm{n}=20)[195]$ & & & & & \\
\hline & Asp f 7 & $46^{\mathrm{d}}(\mathrm{n}=54)[73]$ & & + & 12 & AJ223315 & {$[73]$} \\
\hline & & $29^{c}(n=35)[73]$ & & & & & \\
\hline & Asp $f 8$ & & acid ribosomal protein $\mathrm{P} 2$ & + & 11 & AJ224333 & {$[91]$} \\
\hline & Asp f 9 & $89^{\mathrm{d}}(\mathrm{n}=54)[73]$ & & + & 34 & AJ223327 & [73] \\
\hline & & $31^{\mathrm{c}}(\mathrm{n}=35)[73]$ & & & & & \\
\hline & Asp f 10 & $28^{\mathrm{d}}(\mathrm{n}=54)[73]$ & aspartic protease & + & 34 & X85092 & [198] \\
\hline & & $3^{c}(\mathrm{n}=35)[73]$ & & & & & \\
\hline & Asp f 11 & $90(\mathrm{n}=30)[199]$ & peptidyl-prolyl isomerase & + & 24 & AJ006689 & $\begin{array}{l}{[200,} \\
201]\end{array}$ \\
\hline & Asp f 12 & & HSP90 & + & 90 & U92465 & [92] \\
\hline & Asp f 13 & & alkaline serine protease & + & 34 & Z11580 & [202] \\
\hline & (Asp f 15) & & serine protease & & 16 & AJ002026 & [203] \\
\hline & (Asp f 16) & $70^{\mathrm{g}}(\mathrm{n}=26)[204]$ & & + & 43 & AF062651 & [204] \\
\hline & Asp $\mathrm{f} 17$ & & & + & 27 & AJ224865 & [205] \\
\hline & Asp f 18 & & vacuolar serine protease & + & 34 & Y13338 & [93] \\
\hline & Asp f 22 & & enolase & & 46 & AF284645 & [96] \\
\hline & Asp f 23 & $26.7^{\mathrm{g}}(\mathrm{n}=30)[206]$ & L3 ribosomal protein & + & 44 & AF464911 & [206] \\
\hline & Asp f 27 & & cyclophilin & + & 18 & & [150] \\
\hline & Asp f 28 & & thioredoxin & + & 12 & & [152] \\
\hline & Asp f 29 & & thioredoxin & & 12 & & \\
\hline & Asp f 34 & & PhiA cell wall protein & & 19.3 & AM496018 & \\
\hline & (Asp f $56 \mathrm{kDa})$ & $75.5^{\mathrm{g}}(\mathrm{n}=12)[207]$ & protease & + & 56 & & [207] \\
\hline & Asp f GST & & GST & & 26 & & [187] \\
\hline \multirow{6}{*}{$\begin{array}{l}\text { Aspergillus nidulans } \\
\text { Aspergillus niger }\end{array}$} & Aspe ni 2 & & & + & 29 & Z50175 & [208] \\
\hline & Asp n 14 & $4^{\mathrm{h}}(\mathrm{n}=171)[209]$ & $\beta$-xylosidase & + & 105 & AF108944 & [209] \\
\hline & Asp n 18 & & vacuolar serine protease & + & 34 & M96758 & [210] \\
\hline & Asp n 25 & $36.8^{\mathrm{i}}(\mathrm{n}=38)[211]$ & 3-phytase B (phosphatase) & + & 84 & P34754 & $\begin{array}{l}{[211,} \\
212]\end{array}$ \\
\hline & Asp n glucoamylase & $\begin{array}{c}8^{\mathrm{h}}(\mathrm{n}=171)[209] \\
19^{\mathrm{j}}(\mathrm{n}=24)[213]\end{array}$ & glucoamylase & + & & & [214] \\
\hline & Asp n hemicellulase & $43^{j}(n=24)[213]$ & hemicellulase & + & & & [215] \\
\hline Aspergillus oryzae & Asp o 13 & & alkaline serine protease & + & 34 & X17561 & $\begin{array}{l}{[210,} \\
216]\end{array}$ \\
\hline
\end{tabular}


Table 2 (continued)

\begin{tabular}{|c|c|c|c|c|c|c|c|}
\hline Species & Allergen & $\begin{array}{l}\text { Prevalence } \\
\%\end{array}$ & Biochemical name & RA & $\begin{array}{l}\text { MW } \\
\mathrm{kDa}\end{array}$ & $\begin{array}{l}\text { GenBank } \\
\text { Accession No. }\end{array}$ & Ref. \\
\hline & Asp o 21 & $\begin{array}{c}67^{\mathrm{j}}(\mathrm{n}=24)[213] \\
23^{\mathrm{h}}(\mathrm{n}=171)[209] \\
0.9^{\mathrm{k}}(\mathrm{n}=679)[217] \\
1^{\mathrm{n}}(\mathrm{n}=529)[218] \\
6.2^{\mathrm{n}}(\mathrm{n}=259)[219] \\
31.4^{\mathrm{n}}(\mathrm{n}=207)[221]\end{array}$ & TAKA-amylase A & + & 53 & $\begin{array}{l}\text { D00434, } \\
\text { M33218 }\end{array}$ & [220] \\
\hline & Asp o lactase & $28.7^{\circ}(\mathrm{n}=94)[222]$ & & + & & & [223] \\
\hline & Asp o lipase & & & + & & & [224] \\
\hline \multirow[t]{4}{*}{ Beauveria bassiana } & Bb-Eno 1 & & enolase & & 47.4 & DQ767719 & [225] \\
\hline & $\mathrm{Bb}-\mathrm{f} 2$ & & & & 28.6 & DQ767720 & [225] \\
\hline & Bb-Ald & & aldehyde dehydrogenase & & 53.9 & DQ767721 & [225] \\
\hline & Bb-Hex & & $\mathrm{N}$-acetylhexosaminidase & & 72 & DQ767722 & [225] \\
\hline \multirow[t]{6}{*}{ Candida albicans } & Cand a 1 & & alcohol dehydrogenase & + & 40 & X81694 & [226] \\
\hline & Cand a 3 & $56.25^{1}(\mathrm{n}=16)[227]$ & peroxisomal membrane protein & + & 29 & AY136739 & [227] \\
\hline & Cand a CAAP & $36.7^{\mathrm{p}}(\mathrm{n}=49)[111]$ & acid protease & & & & [111] \\
\hline & Cand a CyP & $>50^{\mathrm{b}}(\mathrm{n}=21)[228]$ & cyclophilin (rotamase) & + & 18 & & [148] \\
\hline & Cand a enolase & $37(\mathrm{n}=54)[229]$ & enolase & + & & L04943 & $\begin{array}{l}{[230,} \\
231]\end{array}$ \\
\hline & Cand a HSP90 & & HSP90 & & 90 & & [232] \\
\hline \multirow[t]{2}{*}{ Candida boidinii } & Cand b 2 & $100^{\mathrm{m}}(\mathrm{n}=89)[84]$ & peroxisomal membrane protein & + & 20 & J04984, J04985 & $\begin{array}{l}{[84,} \\
129]\end{array}$ \\
\hline & Cand b FD & & formate dehydrogenase & & 40.2 & AJ011046 & [233] \\
\hline \multirow[t]{14}{*}{ Cladosporium herbarum } & Cla h 1 & & & & 13 & & {$[234]$} \\
\hline & Cla h 2 & & & & 23 & & [234] \\
\hline & Cla h 5 & & acid ribosomal protein $\mathrm{P} 2$ & + & 11 & X78223 & $\begin{array}{l}{[48,} \\
235]\end{array}$ \\
\hline & Cla h 6 & $22[61]$ & enolase & + & 46 & X78226 & {$[48]$} \\
\hline & Cla h 7 & & flavodoxin (YCP4 homolog) & + & 22 & X78224 & {$[48]$} \\
\hline & Cla h 8 & $57.1(\mathrm{n}=21)[49]$ & mannitol dehydrogenase & + & 28.3 & AY191816 & [49] \\
\hline & Cla h 9 & $19.2(\mathrm{n}=26)[143]$ & vacuolar serine protease & + & 55 & AY787775 & \\
\hline & Cla h 10 & & aldehyde dehydrogenase & + & 53 & $\mathrm{X} 78228$ & {$[48]$} \\
\hline & Cla h 12 & & acid ribosomal protein $\mathrm{P} 1$ & + & 11 & X85180 & [236] \\
\hline & Cla h 8 CSP & & cold shock protein & & 8 & & [237] \\
\hline & Cla h GST & & GST & & & & [147] \\
\hline & Cla h HCh1 & & type I hydrophobin & & 10.5 & AJ496190 & [238] \\
\hline & Cla h HSP70 & & HSP70 & & 70 & X81860 & [53] \\
\hline & Cla h NTF2 & & nuclear transport factor 2 & & 14 & AJ493279 & [189] \\
\hline Cladosporium cladosporoides & Cla c 9 & & vacuolar serine protease & & 36 & EF407520 & \\
\hline \multirow[t]{9}{*}{ Curvularia lunata } & Cur 11 & $80(\mathrm{n}=15)[239]$ & serine protease & & & AY034826 & [239] \\
\hline & Cur 12 & $100^{9}(\mathrm{n}=15)[240]$ & enolase & + & 48 & AY034826 & [240] \\
\hline & Cur 13 & & cytochrome C & & 12 & AY034827 & \\
\hline & Cur $1 \mathrm{ADH}$ & & alcohol dehydrogenase & & 37 & A1YDT6 & \\
\hline & Cur l GST & & GST & & & & [147] \\
\hline & Cur 1 oryzin & & & & 14.2 & AY291575 & \\
\hline & Cur 1 SOD & & SOD & & 21.4 & AY291574 & \\
\hline & Cul 1 Trx & & thioredoxin & & 12.3 & AY291577 & \\
\hline & Cur 1 ZPS1 & & & & 17.3 & AY291573 & \\
\hline Embellisia allii & Emb a 1 & & Alt a 1 related & & & AY563322 & [190] \\
\hline Embellisia indefessa & Emb i 1 & & Alt a 1 related & & & AY563323 & [190] \\
\hline Embellisia novae-zelandiae & Emb nz 1 & & Alt a 1 related & & & AY563324 & [190] \\
\hline Embellisia telluster & Emb t 1 & & Alt a 1 related & & & AY563325 & [190] \\
\hline Epicoccum purpurascens & Epi p 1 & & serine protease & & 30 & P83340 & [241] \\
\hline (Epicoccum nigrum) & Epi p GST & & GST & & 26 & & [147] \\
\hline \multirow[t]{3}{*}{ Fusarium culmorum } & Fus c 1 & $35(\mathrm{n}=26)[242]$ & acid ribosomal protein $\mathrm{P} 2$ & + & 11 & AY077706 & [242] \\
\hline & Fus c 2 & $50(\mathrm{n}=26)[242]$ & thioredoxin-like protein & + & 13 & AY077707 & [242] \\
\hline & Fus c 3 & $15(\mathrm{n}=26)[242]$ & & + & 49 & & [242] \\
\hline \multirow[t]{2}{*}{ Fusarium solani } & Fus s 1 & & & & 65 & P81010 & [243] \\
\hline & Fus s $45 \mathrm{kDa}$ & & enolase & & 45 & & [244] \\
\hline
\end{tabular}


Table 2 (continued)

\begin{tabular}{|c|c|c|c|c|c|c|c|}
\hline Species & Allergen & $\begin{array}{l}\text { Prevalence } \\
\%\end{array}$ & Biochemical name & RA & $\begin{array}{l}\text { MW } \\
\mathrm{kDa}\end{array}$ & $\begin{array}{l}\text { GenBank } \\
\text { Accession No. }\end{array}$ & Ref. \\
\hline Nimbya caricis & Nim c 1 & & Alt a 1 related & & & AY563321 & [190] \\
\hline \multirow{2}{*}{ Penicillium brevicompactum } & Pen b 13 & & alkaline serine protease & & 33 & & [245] \\
\hline & Pen b 26 & & acid ribosomal protein $\mathrm{P} 1$ & + & 11 & AY786077 & [109] \\
\hline \multirow[t]{5}{*}{$\begin{array}{l}\text { Penicillium chrysogenum } \\
\text { (Penicillium notatum) }\end{array}$} & Pen ch 13 & $33^{\mathrm{a}}(\mathrm{n}=212)[246]$ & alkaline serine protease & + & 34 & AF193420 & $\begin{array}{l}{[94} \\
105]\end{array}$ \\
\hline & Pen ch 18 & $\begin{array}{l}76.9^{\mathrm{r}}(\mathrm{n}=13)[106] \\
100^{\mathrm{r}}(\mathrm{n}=8)[107]\end{array}$ & vacuolar serine protease & + & 32 & AF263454 & $\begin{array}{l}{[94,} \\
106]\end{array}$ \\
\hline & Pen ch 20 & & $\mathrm{~N}$-acetyl glucosaminidase & + & 68 & S77837 & [247] \\
\hline & Pen ch 31 & & calreticulin & & 61.6 & AY850367 & \\
\hline & Pen ch 33 & & & & 16 & & \\
\hline \multirow[t]{9}{*}{ Penicillium citrinum } & Pen c 1 & & alkaline serine protease & + & 33 & AF084546 & [248] \\
\hline & Pen c 3 & $46.4^{\mathrm{a}}(\mathrm{n}=28)[108]$ & peroxisomal membrane protein & + & 18 & AF144753 & [108] \\
\hline & Pen c 13 & & alkaline serine protease & & 33 & AF084546 & [248] \\
\hline & Pen c 18 & & vacuolar serine protease & + & 37.3 & AF245168 & [102] \\
\hline & Pen c 19 & $41(\mathrm{n}=34)[103]$ & HSP70 & + & 70 & U64207 & [103] \\
\hline & Pen c 22 & $30.4^{\mathrm{s}}(\mathrm{n}=23)[96]$ & enolase & + & 46 & AF254643 & [96] \\
\hline & Pen c 24 & $7.6^{\mathrm{a}}(\mathrm{n}=92)[110]$ & elongation factor $1 \beta$ & + & 25 & AY363911 & [110] \\
\hline & Pen c 30 & & catalase & & 80.7 & Q2V6Q5 & \\
\hline & Pen c 32 & & pectate lyases & & & EF159713 & \\
\hline Penicillium oxalicum & Pen o 18 & & vacuolar serine protease & + & 34 & AF243425 & $\begin{array}{l}{[94} \\
104]\end{array}$ \\
\hline Pleospora herbarum & Ple h 1 & & Alt a 1 related & & & AY563277 & [190] \\
\hline Stemphylium botryosum & Ste b 1 & & Alt a 1 related & & & AY563274 & [190] \\
\hline \multirow[t]{3}{*}{ Saccharomyces cerevisiae } & Sac c CyP & & cyclophilin (rotamase) & & & & [148] \\
\hline & Sac c enolase & $\begin{array}{l}95(\mathrm{n}=20)[249] \\
20^{\mathrm{t}}(\mathrm{n}=20)[229]\end{array}$ & enolase & & 46.8 & J01322 & $\begin{array}{l}{[96} \\
250]\end{array}$ \\
\hline & Sac c MnSOD & & $\mathrm{MnSOD}$ & & 25.7 & X02156 & [148] \\
\hline \multirow[t]{3}{*}{ Stachybotrys chartarum } & Sta c cellulase & & cellulase/glycosyl hydrolase & & & & [145] \\
\hline & Sta c hemolysin & $38(\mathrm{n}=21)[251]$ & hemolysin & & & & [251] \\
\hline & Sta c stachyrase-A & $80.9(\mathrm{n}=21)[251]$ & & & & & [251] \\
\hline Stemphylium callistephi & Ste c 1 & & Alt a 1 related & & & AY563276 & [190] \\
\hline Stemphylium vesicarium & Ste v 1 & & Alt a 1 related & & & AY563275 & [190] \\
\hline Thermomyces lanuginosus & The 1 lipase & & lipase & & & AF054513 & [252] \\
\hline \multirow[t]{2}{*}{ Trichophyton mentagrophytes } & Tri me 2 & & vacuolar serine protease & & & $\begin{array}{l}\text { AJ430837, } \\
\text { AJ430838, } \\
\text { AJ430839, } \\
\text { AJ430840 }\end{array}$ & \\
\hline & Tri me 4 & & alkaline serine protease & & & AJ430836 & \\
\hline \multirow[t]{2}{*}{ Trichophyton rubrum } & Tri r 2 & & vacuolar serine protease & & & AF082515 & [253] \\
\hline & Tri r 4 & & alkaline serine protease & & & AF082514 & [253] \\
\hline \multirow[t]{2}{*}{ Trichophyton schoenleinii } & Tri sc 2 & & vacuolar serine protease & & & AJ430841 & \\
\hline & Tri sc 4 & & alkaline serine protease & & & AJ430626 & \\
\hline \multirow[t]{2}{*}{ Trichophyton tonsurans } & Tri t 1 & & & & 30 & & [254] \\
\hline & Tri t 4 & & alkaline serine protease & & 83 & P80514 & [253] \\
\hline Ulocladium alternariae & Ulo a 1 & & Alt a 1 related & & & AY563316 & [190] \\
\hline Ulocladium atrum & Ulo at 1 & & Alt a 1 related & & & AY563318 & [190] \\
\hline Ulocladium botrytis & Ulo b 1 & & Alt a 1 related & & & AY563317 & [190] \\
\hline Ulocladium chartarum & Ulo c 1 & & Alt a 1 related & & & AY563319 & [190] \\
\hline Ulocladium cucurbitae & Ulo cu 1 & & Alt a 1 related & & & AY563315 & [190] \\
\hline \multicolumn{8}{|l|}{ BASIDIOMYCOTA } \\
\hline \multirow[t]{5}{*}{ Coprinus comatus } & Cop c 1 & $25^{\mathrm{u}}(\mathrm{n}=92)[121]$ & $\begin{array}{l}\text { transcription factor/leucine } \\
\text { zipper motif }\end{array}$ & + & 11 & AJ132235 & [121] \\
\hline & Cop c 2 & & thioredoxin & + & 11.7 & AJ242791 & \\
\hline & Cop c 3 & & & & & AJ242792 & \\
\hline & Cop c 4 & & & & & & \\
\hline & Cop c 5 & & & + & 15.6 & AJ242793 & \\
\hline
\end{tabular}


Table 2 (continued)

\begin{tabular}{|c|c|c|c|c|c|c|c|}
\hline Species & Allergen & $\begin{array}{l}\text { Prevalence } \\
\%\end{array}$ & Biochemical name & RA & $\begin{array}{l}\mathrm{MW} \\
\mathrm{kDa}\end{array}$ & $\begin{array}{l}\text { GenBank } \\
\text { Accession No. }\end{array}$ & Ref. \\
\hline & Cop c 6 & & & & & & \\
\hline & Cop c 7 & & & & & AJ242794 & \\
\hline \multirow[t]{12}{*}{ Malassezia furfur } & Mal f 1 & $\begin{array}{l}43-61^{\mathrm{v}}(\mathrm{n}=95)[255] \\
17.5^{\mathrm{v}}(\mathrm{n}=40)[256]\end{array}$ & cell wall protein & + & 35.9 & & [257] \\
\hline & Mala f 2 & $71.9^{\mathrm{v}}(\mathrm{n}=64)[130]$ & peroxisomal membrane protein & + & 21 & AB011804 & [130] \\
\hline & Mala f 3 & $70.3^{v}(\mathrm{n}=64)[130]$ & peroxisomal membrane protein & + & 20 & AB011805 & [130] \\
\hline & Mala f 4 & $83.3^{\mathrm{v}}(\mathrm{n}=36)[132]$ & $\begin{array}{l}\text { mitochondrial malate } \\
\text { dehydrogenase }\end{array}$ & + & 35 & AF084828 & [132] \\
\hline & Mal f 5 & $\begin{array}{l}48(\mathrm{n}=25)[131] \\
35^{\mathrm{v}}(\mathrm{n}=40)[256]\end{array}$ & $\begin{array}{l}\text { putative peroxisomal membrane } \\
\text { protein }\end{array}$ & + & 18.2 & AJ011955 & [131] \\
\hline & Mala f 6 & $92(\mathrm{n}=48)[199]$ & putative cyclophilin & + & 17.2 & AJ011956 & [131] \\
\hline & & $>50^{\mathrm{b}}(\mathrm{n}=21)[228]$ & & & & & \\
\hline & & $48(\mathrm{n}=25)[131]$ & & & & & \\
\hline & & $40^{\mathrm{v}}(\mathrm{n}=40)[256]$ & & & & & \\
\hline & Mal f 7 & $\begin{array}{l}48(\mathrm{n}=25)[131] \\
40-60^{\mathrm{v}}(\mathrm{n}=25)[258]\end{array}$ & & + & 16.2 & AJ011957 & [131] \\
\hline & Mal f 8 & $\begin{array}{l}24(\mathrm{n}=25)[131] \\
10-18^{\mathrm{v}}(\mathrm{n}=25)[258]\end{array}$ & & + & 19.2 & AJ011958 & [131] \\
\hline & Mal f 9 & $\begin{array}{l}24-36^{\mathrm{V}}(\mathrm{n}=25)[258] \\
20(\mathrm{n}=25)[131]\end{array}$ & & + & 14.0 & AJ011959 & [131] \\
\hline \multirow[t]{10}{*}{ Malassezia sympodialis } & Mala s 1 & $\begin{array}{l}18.9^{y}(\mathrm{n}=127)[259] \\
46^{\mathrm{x}}(\mathrm{n}=97)[260]\end{array}$ & peroxisomal membrane protein & + & & X96486 & [257] \\
\hline & Mala s 5 & $\begin{array}{l}29.1^{\mathrm{y}}(\mathrm{n}=127)[259] \\
19^{\mathrm{x}}(\mathrm{n}=97)[260]\end{array}$ & $\begin{array}{l}\text { putative peroxisomal membrane } \\
\text { protein }\end{array}$ & + & 18.2 & AJ011955 & [131] \\
\hline & Mala s 6 & $\begin{array}{l}25.2^{\mathrm{y}}(\mathrm{n}=127)[259] \\
21^{\mathrm{x}}(\mathrm{n}=97)[260]\end{array}$ & cyclophilin (rotamase) & + & 17 & AJ011956 & [131] \\
\hline & Mala s 7 & $3^{\mathrm{x}}(\mathrm{n}=97)[260]$ & & + & & AJ011957 & [258] \\
\hline & Mala s 8 & $8^{\mathrm{x}}(\mathrm{n}=97)[260]$ & & + & 19 & AJ011958 & [258] \\
\hline & Mala s 9 & $\begin{array}{l}37.6^{\mathrm{y}}(\mathrm{n}=125)[259] \\
24^{\mathrm{x}}(\mathrm{n}=97)[260]\end{array}$ & & + & 37 & AJ011959 & [258] \\
\hline & Mala s 10 & $69^{\mathrm{w}}(\mathrm{n}=28)[133]$ & HSP88 & + & 70 & AJ428052 & $\begin{array}{l}{[97,} \\
133]\end{array}$ \\
\hline & Mala s 11 & $\begin{array}{l}75^{\mathrm{w}}(\mathrm{n}=28)[133] \\
42^{\mathrm{b}}(\mathrm{n}=67)[44]\end{array}$ & MnSOD & + & 23 & AJ548421 & [133] \\
\hline & Mala s 12 & $62^{\mathrm{x}}(\mathrm{n}=21)[261]$ & $\begin{array}{l}\text { glucose-methanol-choline } \\
\text { oxidoreductase }\end{array}$ & + & 67 & AJ871960 & \\
\hline & Mala s 13 & & thioredoxin & + & 12 & & \\
\hline \multirow[t]{2}{*}{ Psilocybe cubensis } & Psi c 1 & & & & & & \\
\hline & Psi c 2 & & cyclophilin (rotamase) & + & 16 & & [136] \\
\hline \multirow[t]{2}{*}{ Rhodotorula mucilaginosa } & Rho m 1 & $21.4(\mathrm{n}=14)[137]$ & enolase & + & 47 & AF382946 & [137] \\
\hline & Rho m 2 & & vacuolar serine protease & + & 31 & AY547285 & {$[63]$} \\
\hline
\end{tabular}

Allergens listed in the 'official list of allergens' of the International Union of Immunological Societies Allergen Nomenclature Subcommittee (http://www.allergen.org/) are shown in black, whereas allergens highlighted in grey are taken from other sources like the Allergome database (http://www.allergome.org/). Prevalence data are given based on published data, the specification of the respective test populations is as follows: ${ }^{\mathrm{a}}$ asthmatics, ${ }^{\mathrm{b}}$ patients with atopic dermatitis, ${ }^{\mathrm{c}}$ A. fumigatus-sensitized asthmatics with ABPA, ${ }^{\mathrm{d}} A$. fumigatus-sensitized asthmatics without ABPA, ${ }^{\mathrm{e}}$ cystic fibrosis patients having ABPA, ${ }^{\mathrm{f}}$ A. fumigatus-sensitized cystic fibrosis patients, ${ }^{g}$ ABPA patients, ${ }^{h}$ bakers with workplace-related symptoms, ${ }^{i}$ subjects occupationally exposed to powdered $A$. niger phytase having work-related respiratory symptoms, ${ }^{j}$ subjects with baker's asthma, ${ }^{\mathrm{k}}$ employees in flour milling and packing operations, ${ }^{1}$ C. albicans CAP testpositive asthmatics, ${ }^{\mathrm{m}} A$. fumigatus-sensitized asthmatics with no C. albicans infection, ${ }^{\mathrm{n}}$ workers formulating and packaging lactase, ${ }^{\circ}$ pharmaceutical workers exposed to lactase, ${ }^{\mathrm{P}}$ asthmatic patients with positive imme- diate skin response to crude $C$. albicans antigen, ${ }^{\mathrm{q}}$ C. lunata IgE-reactive patients suffering from allergic bronchial asthma and/or rhinitis, ${ }^{\mathrm{r}}$ P. chrysogenum IgE-reactive asthmatics, ${ }^{\mathrm{s}}$ Penicillium IgE-reactive asthmatics, ${ }^{\mathrm{t}} \mathrm{C}$. albicans-sensitized patients reactive with the $C$. albicans enolase, " basidiomycete-sensitized individuals, ${ }^{\mathrm{v}} M$. furfur IgE-reactive atopic dermatitis patients, ${ }^{\text {w }}$ M. sympodialis IgE-reactive patients with atopic eczema/dermatitis syndrome, ${ }^{\mathrm{x}}$ M. sympodialis IgE-reactive atopic eczema patients, ${ }^{\mathrm{y}}$ patients with atopic eczema.

If no superscript is given then the test population is allergic against the respective mold. Some Aspergillus allergens are given in parentheses since some inconsistencies have been identified when the coding sequences were compared with their genomic counterparts [97]. RA = Recombinant allergen, stating whether a given allergen has been cloned as a recombinant allergen. In the last column, the first publication of the respective fungal allergen is shown. 
drogenase, enolase, aldehyde dehydrogenase, flavodoxin (YCP4 homolog), acid ribosomal protein $\mathrm{P} 1$ and $\mathrm{P} 2$, heat shock protein (HSP) 70, nuclear transport factor 2 and glutathione-S-transferase (GST), have not only been identified in A. alternata but also in the closely related mold Cladosporium herbarum [48-53].

Most of the A. alternata allergens cloned so far are minor allergens except for Alt a 1 , which is recognized by up to $98 \%$ of A. alternata-sensitized patients [54]. Alt a 1 can be found as a predominant component in mycelial and culture filtrate extracts $[55,56]$. A 20 -mer peptide of Alt a 1 located at the $\mathrm{N}$-terminal end showed weak binding of patients' IgE antibodies and induced antibody synthesis in Balb/c mice indicating that this peptide harbors a linear B-cell and a T-cell epitope [57].

Two clinical studies using recombinant allergens of $A$. alternata have been performed. Unger et al. [58] tested seven A. alternata-allergic patients with Alt a 1 and Alt a 6 (enolase), which is recognized by $15-22 \%$ of $A$. alternata-allergic patients [52, 54]. In this study, all seven $A$. alternata-allergic patients reacted to the two recombinant allergens whereas commercially available fungal extracts partially failed to correctly diagnose the patients allergy. Asturias et al. [54] tested 42 A. alternata-allergic patients with natural and recombinant Alt a 1 (rAlt a 1), rAlt a 2 and rAlt a 6 . Although the prevalence of Alt a 2 was previously determined to be $61 \%$ [59], none of the 42 patients reacted with rAlt a 2 , but 41 of the 42 patients specifically reacted with rAlt a 6 (enolase) and rAlt a 1 . Thus, the combination of Alt a 1 and Alt a 6 (maybe supplemented with one or two additional allergens) is a promising, molecule-based approach for the diagnosis and therapy of A. alternata allergy.

Alt a 1, the major allergen of A. alternata, was analyzed in respect to its B-cell epitopes. Kurup et al. [60] synthesized overlapping decapeptides (12 amino acids) spanning the entire Alt a 1 protein sequence and tested these peptides for their IgE reactivity with patient sera. They identified four linear IgE epitopes whereas two of them (K41-P50 and Y54-K63) showed strong IgE reactivity in all $4 \mathrm{~A}$. alternata-sensitized patients tested.

\section{Cladosporium herbarum}

Airborne spores of $C$. herbarum are prominent causes of fungal allergy and can be found indoors as well as outdoors.

In a study by Tariq et al. [20], 2.9\% of 9814 -year-old children reacted to $C$. herbarum. In their study, C. herbarum together with A. alternata were the third most common causes of sensitization after house dust mite and grass pollen. Mari et al. [46] tested 4,962 patients having respiratory symptoms. The overall incidence of C. herbarum sensitization was $13 \%$, but within the group of patients sensitized to more than two fungal sources, the prevalence of $C$. herbarum sensitization reached $84 \%$. In other words, monosensitization to $C$. herbarum is rather seldom within mold-allergic patients.

So far, 14 allergens have been identified from C. herbarum, whereas seven of them have been cloned as recombinant proteins (table 2). Except for one, all of these allergens are minor allergens with a prevalence of about $20 \%$. The only major allergen, Cla h 8 , an NADPdependent mannitol dehydrogenase, is recognized by $57 \%$ of the C. herbarum-allergic patients and represents a predominant component of the crude extract [49, $61,62]$.

For some of the allergens (e.g. enolase and serine proteases), extensive cross-reactivity was demonstrated (see also Cross-Reactivity and Auto-Reactivity), making these proteins fungal pan-allergens [51, 52, 63].

IgE epitopes of $C$. herbarum enolase have been tested by a PCR-based approach. Ten different peptides spanning the entire protein sequence were tested for their IgE reactivity. Six peptides showed specific IgE reactivity in all patients tested $(n=10)$, whereas the smallest of them, with a length of 69 amino acids, corresponded to the overlapping region of the five other IgE-reactive peptides $[52,64]$.

\section{Aspergillus Species}

The saprophytic genus Aspergillus includes 132 different species. It is distributed ubiquitously in our natural environment and represents a dominant indoor pathogen [65-67]. Aspergillus grows outdoors on decaying vegetation or indoors (e.g. in air conditioning systems) and has the ability to release large quantities of small conidiospores of $2-3 \mu \mathrm{m}$. In case of inhalation, they either reach terminal airways or are deposited in large clusters in the upper respiratory tract $[14,65,68,69]$. Human disorders caused by Aspergillus range from colonization of the respiratory tract, hypersensitivity pneumonitis (extrinsic allergic alveolitis), allergic rhinitis, sinusitis and asthma, to life-threatening systemic invasive aspergillosis and ABPA $[66,68]$. Very often aspergillosis is favored by an impaired immune status of the patient either caused by immunosuppressive treatment after transplantation surgery, HIV infection, certain leukemias or hospitalization under intensive care.

The biological characteristics of Aspergillus are its small spore size, its thermo-tolerance allowing growth at 
human body temperature, its resistance to oxidative killing and its ability to produce small metabolites and enzymes with proteolytic or even immunosuppressive activity [70-72].

Since A. fumigatus is implicated in about $80 \%$ of Aspergillus-related infections, a large number of allergens were cloned from cDNA and phage display libraries, and characterized and purified as recombinant proteins $[70$, 73-75]. The spectrum of the more than 40 IgE-binding components of $A$. fumigatus that account for the complex, variable and heterogeneous pattern obtained in Western blot experiments includes for example acid ribosomal proteins, enzymes such as proteases, toxins, HSPs as well as several unique proteins exhibiting no significant sequence homologies to structures already deposited in the databases $[69,76]$. At molecular level, all these molecules differ in their allergenicity and can be subdivided into two separate categories, namely secreted and cytoplasmic proteins.

Among the most important A. fumigatus allergens identified through molecular approaches is Asp f 1, a non-glycosylated $18-\mathrm{kDa}$ major allergen originally detected in the urine of patients suffering from invasive aspergillosis. It is related to ribotoxins, which are known to inhibit protein translation by cleaving a conserved region of the $28 \mathrm{~S}$ acid ribosomal RNA [77]. Asp f 1, which was considered to be a kind of virulence factor promoting colonization as well as infection of human tissue, seems to be abundantly secreted after spore germination and during early phases of fungal growth [71, 78]. Although it is recognized by $85 \%$ of ABPA patients as well as A. fumigatus SPT-positive asthmatics, its effectiveness in diagnosis and therapy is still controversial because of its high toxicity $[68,69,79]$. Asp $\mathrm{f} 1$ is one of the A. fumigatus allergens which have been analyzed regarding B- and T-cell epitopes. Kurup et al. [78] synthesized 13 linear decapeptides spanning the whole Asp f 1 molecule and tested them for their IgE reactivity and their potency to stimulate peripheral blood mononuclear cells from ABPA patients. They revealed several peptides harboring $\mathrm{B}$ - and T-cell epitopes, whereas the C-terminal region (aa 115 149) was shown to be involved in humoral as well as in cell-mediated immunoresponses in ABPA. Most of the Asp $\mathrm{f}$ 1-specific T-cell clones reacted with the peptides aa 46-65 and aa 106-125 restricted by HLA-DR 2 and HLADR5 alleles [80].

Banerjee et al. [81] performed two studies on the B-cell epitopes of Asp f 2, identifying nine epitopes located in hydrophilic regions [81], with a putative major B-cell epitope at the N-terminus [82]. T-cell clones were generated from ABPA patients using synthetic peptides from Asp $\mathrm{f}$ 2 , identifying aa 54-74 as a major T-cell epitope [83].

The 19-kDa Asp f 3, which shares common IgE-binding epitopes with the peroxisomal membrane proteins $\mathrm{A}$ and B from Candida boidinii, can be regarded as the second major allergen of this fungus (94\% IgE reactivity), with clinical relevance being already demonstrated in vivo by the provocation of mediator release $[67,73,84$, 85]. B-cell epitopes were analyzed using synthetic peptides and constructing Asp f 3 mutants. Ramachandran et al. [86] identified seven linear IgE-binding regions spanning the entire protein sequence. They identified 12 amino acids at the $\mathrm{N}$-terminus and 8 amino acids at the C-terminus to be critical for IgE binding.

In case of Asp $\mathrm{f} 4$, three cysteine deletion mutants were generated by selectively deleting cysteine residues. These mutants reacted differently with the IgE antibodies from ABPA patients. The authors concluded that the N-terminal IgE-epitope regions of the protein are crucial for the maintenance of the proper three-dimensional structure whereas the C-terminal cysteines play a significant supporting role in IgE binding [87].

Asp f 6, an MnSOD, represents a phylogenetically highly conserved protein belonging to the metalloenzyme superfamily, which is required for the conversion of superoxide radicals to hydrogen peroxide and oxygen [88]. Since Asp f 2, Asp f 4, whose biological function still is unresolved, and the MnSOD Asp $\mathrm{f} 6$ are strictly intracellular proteins and thus very unlikely to be available as aeroallergens under normal conditions, sensitization against these two marker molecules seems to be sufficient to allow a precise diagnosis of ABPA [70, 89, 90]. ABPA is the result of fungal proliferation in the respiratory tract, exposing especially atopic asthmatics and patients suffering from cystic fibrosis to non-secreted $A$. fumigatus allergens due to cellular defense mechanisms and fungal damage [76].

A. fumigatus acid ribosomal protein $\mathrm{P} 2$, Asp $\mathrm{f} 8$, shows a high degree of conservation among eukaryotic organisms and is characterized by the presence of cross-reactive epitopes shared with the homologous allergens from C. herbarum and A. alternata $[48,91]$.

Asp f 12, a HSP90 protein, may play a major role during stress response and possesses considerable homology to the HSP90 molecules from C. albicans, S. cerevisiae, Trypanosoma, housefly, mouse and homo sapiens. Asp $\mathrm{f}$ 12 is also thought to play a role in ABPA and other Aspergillus-induced diseases [92].

Furthermore, alkaline as well as vacuolar serine proteases have been identified to be major allergens in case 
of A. fumigatus (Asp f 13 and Asp f 18), A. flavus (Asp fl 13 and Asp fl 18) and A. oryzae (Asp o 13) sharing IgE and IgG epitopes with each other as well as with fungal serine proteases from Penicillium spp. (Pen b 13, Pen c 13, Pen n 13, Pen n 18 and Pen o 18) [68, 93,94]. In order to analyze the B-cell epitopes from Asp f 13, the protein was chemically and enzymatically cleaved and subsequently the N-terminal sequences were determined. At the end, 3 of 13 linear epitopes located at the C-terminus were proven to be immunodominant [95].

Another important A. fumigatus allergen is enolase (Asp f 22), a protein of $47 \mathrm{kDa}$, whose cross-reactivity with Pen c 22 (Penicillium citrinum), Alt a 6 (A. alternata) and Cla h 6 (C. herbarum) has been proven by inhibition immunoblotting [52, 96].

Recently, Bowyer and Denning [97] compared previously published $A$. fumigatus allergen sequences with $A$. fumigatus genomic sequences and revealed that Asp $\mathrm{f} 15$ is identical to Asp f 13. Additionally, they observed partial homology between Asp f 16 and Asp f 9, whereas the Asp f 16 sequence, in contrast to the Asp f 9 sequence, could not be localized on two different $A$. fumigatus genomic sequences. Assuming either sequencing errors or the existence of an isoform, the authors concluded that the Asp $\mathrm{f} 9$ sequence is more reliable and that Asp $\mathrm{f} 16$ also should be termed Asp f 9. In case of the Asp f $56-\mathrm{kDa}$ allergen, the authors could not find any corresponding genomic sequence. Since these new results have not been included into the WHO allergen list so far, the respective allergens were kept in the list of fungal allergens (table 2) but were parenthesized.

Additionally, A. oryzae $\alpha$-amylase (Asp o 21) and A. niger $\beta$-xylosidase (Asp n 14), which are used as baking additives in the food industry as well as in the starch industry, show allergenic activity $[65,67]$.

Recombinant Asp f 1, rAsp f 4, rAsp f 6 (MnSOD) and rAsp $\mathrm{f} 8$ (acid ribosomal protein $\mathrm{P} 2$ ), have been tested in several clinical studies $[84,85,88,91]$ involving patients suffering from asthma, ABPA and AD. In these studies, the diagnostic specificity was better in case of recombinant $A$. fumigatus allergens, and additionally no adverse reactions have been reported.

\section{Penicillium Species}

More than 150 Penicillium species exist, some of which have been described to be common indoor molds. Wei et al. [98] analyzed 88 homes in the Taipei area in order to isolate and identify the indoor Penicillium species. Their results showed that $P$. citrinum is the most common Penicillium species in this area. Muilenberg et al. [99] have reported that $P$. citrinum, $P$. oxalicum and Penicillium chrysogenum (former $P$. notatum) are the five most frequently encountered species of Penicillium in Topeka (Kans., USA). Penicillium can cause atopic asthma in sensitive persons after inhalation of their spores [100]. In Taiwan, $22 \%$ of the asthmatic children showed a positive reaction in intracutaneous skin tests for Penicillium species [101]. Shen et al. [93] showed that IgE antibodies against components of $P$. citrinum, $P$. notatum, $P$. oxalicum and $P$. brevicompactum could be detected in the sera of $16-24 \%$ of asthmatic patients. In 100 patients, $P$. chrysogenum had the highest positive intradermal skin test reactivity (68\%). Therefore, P. chrysogenum is the most frequent Penicillium species used for the clinical diagnosis of fungal allergy.

Results from Shen et al. [93] showed that $80-93 \%$ of asthmatics displayed IgE reactivity to the $32-$ to $34-\mathrm{kDa}$ serine proteases from $P$. citrinum, $P$. chrysogenum, $P$. oxalicum, $P$. brevicompactum, A. fumigatus, A. flavus, $A$. oryzae and $A$. niger, suggesting a role as major allergens. Alkaline and vacuolar serine proteases from Aspergillus and Penicillium were termed group 13 and group 18 allergens, respectively, by the World Health OrganizationInternational Union of Immunological Societies Allergen Nomenclature Subcommittee [93], whereby there also exist homologous and partially cross-reactive alkaline and serine proteases in other fungal species (table 3; see also Cross-Reactivity and Auto-Reactivity). Serine proteases are expressed as large precursor molecules which are posttranslationally cleaved forming the mature enzymes. Besides N-terminal cleavage of a pre-prosequence, which has been described for all serine proteases during maturation [94, 102-104], Pen c 18 and Pen o 18 also undergo C-terminal processing [104].

The alkaline serine protease Pen ch 13 was analyzed for linear IgE epitopes. Eleven peptide fragments spanning the whole molecule were generated and tested for their IgE reactivity in dot blot immunoassays. Determination of the IgE reactivity [105] revealed that peptide f$2 \mathrm{n}$ (aa 31-61) showed the highest frequency $(77.1 \%, \mathrm{n}=$ 35). Three further peptides were IgE reactive with incidences ranging from 31 to $51 \%$. The B-cell epitope analysis was refined by narrowing down peptide $\mathrm{f}-2 \mathrm{n}$ and sitedirected mutagenesis of Pen ch 13. Finally, one major linear B-cell epitope was identified to be located within aa 48-55.

In case of Pen ch 18, a dominant linear IgE epitope was mapped within aa 73-95 of the $\mathrm{N}$-terminally processed allergen [106]. A similar result was observed by Yu et al. [107] who located nine different IgE-binding epitopes 
Table 3. Cross- and/or auto-reactive fungal allergens

\begin{tabular}{lll} 
Cross-reactivity & \\
\hline $\begin{array}{l}\text { within } 1 \text { fungal } \\
\text { phylum }\end{array}$ & $\begin{array}{l}\text { between fungal } \\
\text { phyla }\end{array}$ & $\begin{array}{l}\text { with non-fungal } \\
\text { species }\end{array}$ \\
\hline
\end{tabular}

\section{Aldehyde dehydrogenase}

Alternaria alternata

Beauveria bassiana

Cladosporium herbarum

Harmonia axyridis

\section{Alt a 1 related}

Alternaria argyranthemi

Alternaria brassicicola

Alternaria blumeae

Alternaria brassicae

Alternaria capsici

Alternaria carotiincultae

Alternaria cetera

Alternaria cheiranthi

Alternaria cinerariae

Alternaria conjuncta

Alternaria crassa

Alternaria cucumerina

Alternaria dauci

Alternaria dumosa

Alternaria eryngii

Alternaria ethzedia

Alternaria euphorbiicola

Alternaria japonica

Alternaria limoniasperae

Alternaria longipes

Alternaria macrospora

Alternaria metachromatica

Alternaria mimicula

Alternaria mouchaccae

Alternaria oregonensis

Alternaria petroselini

Alternaria photistica

Alternaria porri

Alternaria pseudorostrata

Alternaria radicina

Alternaria solani

Alternaria smyrnii

Alternaria sonchi

Alternaria tagetica

Alternaria tenuissima

Embellisia allii

Embellisia indefessa

Embellisia novae-zelandiae

Embellisia telluster

Nimbya caricis

Pleospora herbarum

Stemphylium botryosum

Stemphylium callistephi

Stemphylium vesicarium

Ulocladium alternariae

Ulocladium atrum

Ulocladium botrytis

Ulocladium chartarum

Ulocladium cucurbitae

$\begin{array}{ll}\text { Alt a } 10 & + \\ \text { Bb-Ald } & + \\ \text { Cla h } 10 & +\end{array}$

Har a 2

Alt $\arg 1+$

Alt b $1+$

Alt bl $1+$

Alt br 1

Alt c 1

Alt ca 1

Alt ce 1

Alt ch 1

Alt ci 1

Alt co 1

Alt cr 1

Alt cu 1

Alt d 1

Alt du 1

Alt e 1

Alt et 1

Alt eu 1

Alt $j 1$

Alt 11

Alt lo 1

Alt $\mathrm{m} 1$

Alt me 1

Alt mi 1

Alt mo 1

Alt o 1

Alt p 1

Alt ph 1

Alt po 1

Alt ps 1

Alt $\mathrm{r} 1$

Alt s 1

Alt sm 1

Alt so 1

Alt t 1

Alt te 1

Emb a 1

Emb i 1

Emb nz 1

Emb t 1

Nim c 1

Ple h 1

Ste b 1

Ste c 1

Ste v 1

Ulo a 1

Ulo at 1

Ulo b 1

Ulo c 1

Ulo cu 1
+
+

(2)


Table 3 (continued)

Cross-reactivity

within 1 fungal

phylum

between fungal phyla

Asp f 11

Asp f 27

Bet v 7

Cand a CyP

Cat $r 1$

Dauc c cyclophilin

Hom s CyP A

Hom s CyP B

Hom s CyP C

Mala 5

Mala s 6

Psi c 2

Sac c Cyp

\section{Alt a 6}

Asp f 22

Bb-Eno 1

Cand a enolase

Cla h 6

Cur 12

Cyn d 22

Hev b 9

Pen c 22

Rho $m 1$

Sac c enolase

+
+
+
+ with non-fungal species

Hevea brasiliensis

Penicillium citrinum

Rhodotorula mucilaginosa

Saccharomyces cerevisiae

\section{Alt a 7}

Cla h 7

YCP4

$\begin{array}{ll}+ & \\ + & + \\ + & + \\ & + \\ & + \\ & + \\ & + \\ & +\end{array}$

\section{Flavodoxin (YCP4 homolog)}

Alternaria alternata

Cladosporium herbarum

Saccharomyces cerevisiae

\section{GST}

Alternaria alternata

Aspergillus fumigatus

Blattella germanica

Blomia tropicalis

Cladosporium herbarum

Curvularia lunata

Dermatophagoides farinae

Epicoccum purpurascens

Sarcoptes scabiei

$\begin{array}{ll}+ & \\ + & + \\ + & \\ + & \\ + & + \\ & \\ & \\ + & \\ + & \\ + & \end{array}$

\section{HSP70}

Alternaria alternata

Blomia tropicalis

Cladosporium herbarum

Dermatophagoides farinae

Penicillium citrinum

Toxoplasma gondii

Mannitol dehydrogenase

Alternaria alternata

Cladosporium herbarum
Alt a 13

Asp f GST

Bla g 5

Blot 8

Cla h GST

Cur l GST

Derf 8

Der $\mathrm{p} 8$

Epi p GST

Sar s GST

\section{Alt a 3}

Blo t HSP70

Cla h HSP70

Der f HSP70

Pen c 19

Tox g HSP70
$+$

$+$

Alt a 8

Cla h 8

+
+

+
+

$+$

$+$

+
+

\begin{tabular}{ll}
+ & + \\
+ & + \\
+ & + \\
& + \\
\hline
\end{tabular}

$\begin{array}{ll}\text { Alt a } 8 & + \\ \text { Cla h } 8 & +\end{array}$

Simon-Nobbe/Denk/Pöll/Rid/

Breitenbach 
Table 3 (continued)

Cross-reactivity

within 1 fungal between fungal with non-fungal

phylum

\section{MnSOD}

Aspergillus fumigatus

\section{Asp f 6}

Cur 1 SOD

Dro m MnSOD

Hev b 10

Hom s MnSOD

Mala s 11

Ole e 5

Sac s MnSOD

\section{$+$}

$+$

$+$

Saccharomyces cerevisiae

NTF2

Alternaria alternata

Cladosporium herbarum

Alt a NTF2

Cla h NTF2

$+$

$+$

\section{Peroxisomal membrane protein}

Aspergillus fumigatus

Candida albicans

Candida boidinii

Malasezzia furfur
Asp f 3
Cand a 3
Cand $\mathrm{b} 2$
Mala f 2
Mala f 3
Mal f 5
Mala s 1
Pen c 3

$\begin{array}{rr} & + \\ & + \\ & + \\ + & + \\ + & +\end{array}$

Malasezzia sympodialis Penicillium citrinum

Alt a 12

Cla h 12

Pen b 26

Alt a 5

Asp f 8

Cla h 5

Fus c 1

Homo s P2

Pru du 5

Api $m 7$

Cuc $m 1$

Cur 11

Epi p 1

Per a 10 w

Pol d 4

Pol e 4

Asp fl 13

Asp $f 13$

Asp o 13

Bac l subtilisin

Pen b 13

Pen ch 13

Pen c 13

Tri me 4

Tri $r$

Tri sc 4

Tri t 4

13
3
3
3
13
3
4
4

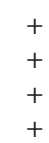

$+$

$+$

$+$

$+$

$+$

$+$

$+$

$+$

Penicillium citrinum

Trichophyton mentagrophytes

Trichophyton rubrum

Trichophyton schoenleinii

Trichophyton tonsurans

$\begin{array}{ll} & + \\ + & + \\ + & \\ & + \\ & + \\ & +\end{array}$

Aspergillus flavus

Aspergillus oryzae 
Table 3 (continued)

\begin{tabular}{|c|c|c|c|c|}
\hline & & \multicolumn{3}{|l|}{ Cross-reactivity } \\
\hline & & $\begin{array}{l}\text { within } 1 \text { fungal } \\
\text { phylum }\end{array}$ & $\begin{array}{l}\text { between fungal } \\
\text { phyla }\end{array}$ & $\begin{array}{l}\text { with non-fungal } \\
\text { species }\end{array}$ \\
\hline \multicolumn{5}{|l|}{ Vacuolar serine protease } \\
\hline Aspergillus flavus & Asp fl 18 & & + & \\
\hline Aspergillus fumigatus & Asp f 18 & & + & \\
\hline Aspergillus niger & Asp n 18 & & + & \\
\hline Cladosporium herbarum & Cla h 9 & & + & \\
\hline Cladosporium cladosporioides & Cla c 9 & & + & \\
\hline Penicillium chrysogenum & Pen ch 18 & & + & \\
\hline Penicillium citrinum & Pen c 18 & & + & \\
\hline Penicillium oxalicum & Pen o 19 & & + & \\
\hline Rhodotorula mucilaginosa & Rho $\mathrm{m} 2$ & & + & \\
\hline Trichophyton mentagrophytes & Tri me 2 & & + & \\
\hline Trichophyton rubrum & Tri r 2 & & + & \\
\hline Trichophyton schoenleinii & Tri sc 2 & & + & \\
\hline \multicolumn{5}{|l|}{ Thioredoxin } \\
\hline \multirow[t]{2}{*}{ Aspergillus fumigatus } & Asp f 28 & & + & \\
\hline & Asp f 29 & & + & \\
\hline Coprinus comatus & Cop c 2 & & + & \\
\hline Curvularia lunata & Cur 1 Trx & & + & \\
\hline Fusarium culmorum & Fus c 2 & & + & \\
\hline Hevea brasiliensis & Hev b Trx & & & + \\
\hline Homo sapiens & Homo s Trx & & & + \\
\hline Malasezzia sympodialis & Mala s 13 & & + & \\
\hline Triticum aestivum & Tri a 25 & & & + \\
\hline Zea mays & Zea m 25 & & & + \\
\hline
\end{tabular}

For each cross- and/or auto-reactive allergen, a list of fungal species is given where the respective allergen has been identified. Additionally, the name of the allergen is listed along with the information whether cross-reactivity occurs within one fungal phylum, within several fungal phyla or even within non-fungal species. Allergen names deposited in the official allergen list are shown in black, all others in grey. NTF2 $=$ Nuclear transport factor 2 . distributed throughout the whole protein. One peptide, peptide C12 (V44-W62), was also located at the N-terminal end and was recognized by $75 \%(n=8)$ of the patients tested.

Besides the highly cross-reactive serine proteases, several other Penicillium allergens have been identified. In case of $P$. citrinum, six allergens have been identified. One of them is Pen c 3, a peroxisomal membrane protein. Thirteen out of 28 (46.4\%) sera of Penicillium-sensitized asthmatic patients demonstrated IgE binding to Pen $\mathrm{c} 3$. Immunoblot inhibition experiments showed cross-reactivity between Pen c 3 and Asp f 3, which share 82.6\% sequence identity [108].

Another $P$. citrinum-allergen was described to be HSP70. Members of the 70-kDa heat shock gene family are highly conserved across a wide range of organisms. They assist the proper folding of polypeptides, inhibit protein aggregation and target misfolded proteins for degradation. The new allergen was designated Pen c 19, and 14 out of 34 (41\%) allergic patients showed IgE binding to the recombinant and natural allergen [103].

A 47-kDa IgE-reactive component was shown to be an enolase (Pen c 22) being cross-reactive with enolases from A. fumigatus and A. alternata. Seven out of 23 (30.4\%) sera of Penicillium-sensitized asthmatic patients reacted with a $47-\mathrm{kDa} P$. citrinum protein from the extract and the recombinant Pen c 22, respectively $[96,109]$.

Pen c 24, elongation factor $1 \beta$ (EF-1 $\beta$ ), shows a sequence identity of $53 \%$ with its yeast (S. cerevisiae) homo$\log$ [110]. The N-terminal (aa 1-118) half of the protein was recognized by 2 out of 7 Pen c 24-reactive patient sera, whereas 5 out of 7 sera reacted to the C-terminal half (aa 119-228) [110], indicating that on both halves B-cell epitopes are present. 
An acid ribosomal protein, $\mathrm{P} 1$, was characterized to be an allergen of $P$. brevicompactum by Sevinc et al. [109]. It was designated Pen b 26, and only sera of individuals who were sensitized to this mold reacted with the protein. It is a polypeptide of $11 \mathrm{kDa}$, rich in acidic residues $(>20 \%)$ and its isoelectric point is 3.87 .

\section{Candida albicans}

Although six C. albicans allergens have been described so far, it is still controversial whether the inhalation of this mold is causative for its allergenicity $[111,112]$.

Cand a enolase, for example, was isolated and analyzed for its B-cell epitopes by testing six proteolytic fragments for their IgE reactivity [113]. Ito et al. [113] identified a C-terminal fragment (F-171-I-399), which reacted to $90 \% \operatorname{IgE}$ antibodies examined $(\mathrm{n}=10)$. A similar result was obtained by Eroles et al. [114], who also demonstrated the high immunogenicity of the $\mathrm{C}$-terminus.

\section{Allergens from the Basidiomycota}

Among fungi, the basidiomycota are a very large phylum comprising approximately 20,000 species including puffballs, bracket fungi, toad stools, jelly fungi, plant rusts, smuts and mushrooms like the edible Boletus, Cantharellus and Coprinus. Of the large number of basidiomycete species, about 25 species have been shown to be allergenic [115]. Basidiospores contribute most of all to the airborne fungal spore load ranging from 5 to $30 \%[8$, $65,116]$. They particularly occur outdoors, but can also be found indoors, e.g. on wet decaying wood or as infiltrates from outdoors. In temperate zones, seasonal peaks of basidiospores are observed in spring and autumn [116]. The diameter of basidiospores ranges from 3 to $15 \mu \mathrm{m}$ enabling them to reach the lower respiratory tract [117]. In contrast to ascomycota, basidiomycota do not have vegetative spore production. Since not only the spores but also the fruiting bodies of Ganoderma, Coprinus and Pleurotus contain allergens, they may induce food allergy in sensitized patients upon consumption of these mushrooms $[118,119]$. Hence, basidiomycota as well as ascomycota are known to cause atopic asthma in susceptible persons [120]. The incidence of basidiomycota-caused allergy ranges from 3.5 [121] to $25.4 \%$ [122].

In a study performed in Europe and the USA [122], a total of 701 adults were tested for their reactivity to eight basidiomycete species. The majority (70\%) of the individuals tested were classified to be atopic. Out of these 701 persons, $25.4 \%$ reacted to at least one basidiomycete ex- tract, whereas Psilocybe cubensis elicited most of the positive skin reactions (13.7\%) followed by Pleurotus ostreatus (10.6\%), Ganoderma meredithae (9.3\%) and Coprinus quadrifidus (5.4\%). In a study by Helbling et al. [123], $9.8 \%$ of atopic subjects, who were not preselected with regard to mold allergy, were sensitized to at least one basidiomycete species. Within 457 atopic patients, $8.3 \%$ reacted to Pleurotus pulmonalis, $6.2 \%$ to Coprinus comatus and $5.4 \%$ to Boletus edulis. Moreover, they found that only $4 \%$ of the basidiomycete-sensitive subjects were exclusively skin test positive to basidiomycete extracts.

Up to now, the knowledge about basidiomycete allergens lags behind the information about ascomycete allergens. One of the reasons is the lack of source material since cultivation of basidiomycetes is much more complicated and in some cases even impossible.

\section{Coprinus comatus}

Among basidiomycota-sensitized patients, C. comatus shows a sensitization rate of 58\% [123]. In 1999, Cop c 1 was cloned. It harbors two leucine zipper motifs. Its biologic function is unknown, and it represents a minor allergen being recognized by $25 \%$ of $C$. comatus-sensitized patients [121]. In sensitized individuals, Cop c 1 is skin test reactive in the picomolar range, making it a clinically relevant allergen [121]. Six further allergens with an open reading frame between 68 and 342 amino acids were isolated, whereas only in case of Cop c 2 (thioredoxin) any homology to previously isolated proteins was observed [124].

Malassezia furfur

M. furfur, previously also known as Pityrosporum ovale or Pityrosporum orbiculare, is a member of the normal cutaneous flora, preferentially colonizing the skin of the head-neck-face region as single-cell yeast, normally being non-pathogenic [125]. Nevertheless, this yeast can act as a pathogen causing pityriasis versicolor and seborrheic dermatitis [41, 126].

IgE reactivity to $M$. furfur, as shown in skin tests and radioallergosorbent tests, has frequently been observed in patients with $\mathrm{AD}$ [127]. M. furfur contains several IgEreactive proteins ranging from 14 to $94 \mathrm{kDa}$ [128].

Mala $\mathrm{f}$ and Mala $\mathrm{f} 3$ are peroxisomal proteins forming homodimers with an apparent molecular weight of 21 and $20 \mathrm{kDa}$, respectively, under reducing conditions in SDS-PAGE. They have a sequence identity of $51 \%$ and exhibit a high sequence similarity with Asp f 3 from $A$. $f u$ migatus and two peroxisomal membrane proteins from C. boidinii $[84,129]$. In a study of Yasueda et al. [130], 64 
of $127 \mathrm{AD}$ patients reacted with $M$. furfur extract, and 71.9 and $70.3 \%$ were IgE reactive to Mala $\mathrm{f} 2$ and Mala f 3 , respectively, making these proteins major allergens. Lindborg et al. [131] published the isolation of Mala $\mathrm{f} 5$, which again has a high sequence identity with Mala $\mathrm{f} 2$ (57\%) and Mala $\mathrm{f} 3(58 \%)$ and is recognized by $48 \%$ of $M$. furfur extract-reactive patients. Additionally, Mala $\mathrm{f} 6$, a putative cyclophilin, was isolated, having an incidence of IgE reactivity of $48 \%$ [131].

Further allergens identified are Mala f 4, a mitochondrial malate dehydrogenase, with $83.3 \%$ of patients having elevated serum IgE levels to purified Mala f 4 [132].

\section{Malassezia sympodialis}

M. sympodialis as well as M. furfur are associated with AD. Several allergens were cloned, including MnSOD (Mala s 11) and HSP88 (Mala s 10) with IgE reactivities of 75 and $69 \%$, respectively $[97,133]$. First, Mala s 10 was published to be an HSP70 protein [133], but Nierman et al. [134] compared the published allergen sequences with the genomic sequences obtained recently and concluded that this allergen is actually an HSP88 protein.

\section{Psilocybe cubensis}

Skin test reactivity to $P$. cubensis spore extract is the highest (13.7\%) among basidiomycetes in Europe and the USA [122]. More than ten allergens have been identified by SDS-PAGE immunoblots. Psi c 2, the first recombinant basidiomycete allergen (molecular weight: $16 \mathrm{kDa}$ ) shows high homology to cyclophilins and is recognized by $82 \%$, representing a major allergen $[135,136]$.

\section{Rhodotorula mucilaginosa}

Rhodotorula mucilaginosa, also known as R. rubra, is one of the most frequently encountered yeast species in our environment. Chang et al. [137] published the isolation of an enolase (Rho $\mathrm{m} \mathrm{1}$ ) which shows high sequence identity with other fungal IgE-reactive enolases. Rho $\mathrm{m} 1$ is recognized by $21.4 \%$ of $R$. mucilaginosa-sensitized patients and cross-reacts with several fungal enolases. Rho $\mathrm{m} 2$, a vacuolar serine protease, is the second cloned allergen, which also cross-reacts with other fungal vacuolar serine proteases [63].

\section{Cross-Reactivity and Auto-Reactivity}

Cross-reactivity can be seen when IgE antibodies originally directed against a given allergen also bind to a structurally related allergen from another allergen source
[138], thus it is the result of shared B-cell epitopes among homologous proteins. A sequence identity of more than $50 \%$ between homologous allergens seems to be necessary in order to exhibit cross-reactivity [139]. Cross-reactivity may be analyzed by various techniques, e.g. immunoblots, RAST and ELISA inhibition. Cross-reactivity between two allergens of different molds has to be distinguished from 'co-sensitization' of an allergic person to an allergen originating from another allergenic source. Cosensitization and cross-reactivity may be differentiated by inhibition experiments between two extracts originating from distinct fungal species, where the degree of inhibition is determined. Cross-reactivity has been described for about 20 fungal allergens. Partly, the crossreactivity observed may be ascribed to the close phylogenetic relationship of some fungal species. O'Neil et al. [140] performed skin tests with selected ascomycota and basidiomycota species demonstrating an association between P. ostreatus, A. alternata, Fusarium solani and Epicoccum purpurascens, as well as between Calvatia cyathiformis, A. alternata and F. solani. C. quadrifidus was associated with $F$. solani and $P$. cubensis with A. fumigatus. Thus, cross-reactivity is widespread within the two phyla and is one explanation for the clinical observation that the majority of mold-allergic patients react with several fungal species in vitro and/or in vivo [25]. Interestingly, very often cross-reactive fungal allergens represent intracellular proteins, whereas some species-specific mold allergens tend to be secreted, as it was shown for Asp f 1 [71] from A. fumigatus and Cop c 1 [121] from $C$. comatus.

Cross-reactive allergens may be subdivided according to the origin of their cross-reactive partners. In table 3, all cross-reactive fungal allergens are listed, along with the name of the allergen and whether or not the respective cross-reactive allergen can be found within one fungal phylum, all fungal phyla or even non-fungal species. In case of a few allergens, homologous human cross-reactive proteins have also been identified, which may give rise to auto-reactivity. The allergens showing only crossreactivity within one fungal phylum are Alt a 1, flavodoxin (YCP4-homolog), mannitol dehydrogenase, nuclear transport factor 2 and the acid ribosomal protein P1. Cross-reactivity between fungal phyla in general has been obtained in case of peroxisomal proteins and vacuolar serine proteases. More than half of the cross-reactive fungal allergens (aldehyde dehydrogenase, alkaline serine protease, serine protease, enolase, GST and HSP70) have got homologous IgE-reactive proteins in non-fungal species. In four of them (thioredoxin, cyclophilin, MnSOD 
and ribosomal protein $\mathrm{P} 2$ ), cross-reactivity with the human homolog has been observed. Taken together, it is obvious that within the last years the picture has changed in a way that meanwhile more than half of the cross-reactive fungal allergens show cross-reactivity to non-fungal species, raising the importance of fungal allergens in general.

\section{Cross-Reactivity within One Fungal Phylum}

Recently, several fungal species were tested for Alt a 1 homologues using a rabbit-anti-rAlt a 1 serum [141]. The authors could show that cross-reactive proteins were detectable in Stemphylium botryosum, Ulocladium botrytis, Curvularia lunata and Alternaria tenuissima, but not in C. herbarum, P. chrysogenum and A. fumigatus.

\section{Cross-Reactivity within All Fungal Phyla}

Vacuolar Serine Protease. Vacuolar serine proteases have been isolated from Aspergillus, Cladosporium, Penicillium, Rhodotorula and Trichophyton. Lin et al. [142] generated monoclonal antibodies against culture medium and/or crude extract from P. citrinum and A. fumigatus. They obtained five monoclonal antibodies directed against serine proteases. Two of them (FUM20 and PCM39) were shown to be cross-reactive with the vacuolar serine proteases from $P$. notatum, $P$. oxalicum and $A$. fumigatus. From our work [143] we know that these mAbs are also cross-reactive with $\mathrm{Cla} h$ 9, the vacuolar serine protease from $C$. herbarum. Chou et al. [63] demonstrated cross-reactivity for the native and recombinant vacuolar serine proteases from $R$. mucilaginosa and P. chrysogenum.

Peroxisomal Membrane Protein. In a cross-inhibition study, Asp f 3 shared common IgE epitopes with Cand b 2 , previously called peroxisomal membrane proteins $\mathrm{A}$ and $\mathrm{B}$ (PMPA and PMPB) [84].

\section{Cross-Reactivity between Fungal and Non-Fungal} Species

Enolase. Enolase represents an allergen in many fungal species, e.g. C. herbarum, A. alternata, C. albicans, S. cerevisiae, A. fumigatus, F. solani, C. lunata, R. mucilaginosa, Beauveria bassiana and P. citrinum. Preliminary data also indicate that E. purpurascens [144] and Stachybotrys chartarum [145] have got IgE-reactive enolases. Cynodon dactylon and Hevea brasiliensis are the nonfungal species where enolase has been described to be an allergen. The enolases of $C$. herbarum, A. alternata, $A$. fumigatus and C. albicans were shown to be cross-reactive by inhibition experiments [52]. Wagner et al. [146] demonstrated cross-reactivity between A. alternata, $C$. herbarum and Hevea brasiliensis by pre-incubating a serum pool with rHev b 9 and testing this depleted serum with rCla h 6 and rAlt a 6 , where there was no IgE-binding detectable.

Glutathione-S-Transferase. The crude extracts of A. alternata, A. fumigatus, C. herbarum, C. lunata and E. purpurascens were proven to have GST-enzymatic activity. Additionally, in all extracts a $26-\mathrm{kDa}$ protein reacted with anti-GST antibodies. Using these anti-GST antibodies in ELISA inhibition experiments revealed inhibition in case of $C$. herbarum, A. alternata, C. lunata, A. fumigatus and E. purpurascens [147].

\section{Auto-Reactivity}

There is evidence that fungal sensitization also contributes to auto-reactivity against self-antigens due to shared epitopes between fungal and human proteins. The underlying mechanism seems to be molecular mimicry perpetuating severe chronic allergic diseases.

Cross-reactivity between fungal and human proteins has been demonstrated for MnSOD [148, 149], cyclophilin [150], acid ribosomal protein P2 [151] and thioredoxin [152]. Based on our own research on C. herbarum and $A$. alternata allergens, we could show that intracellular fungal proteins are presented to the immune system. Intracellular human proteins are normally not presented to the immune system. However, in case of chronic inflammation, tissue may be damaged and as a consequence these proteins may be accessible for the immune system. Thus human proteins like MnSOD or acid ribosomal protein 2 may sustain allergic symptoms. In a recent study on the pathogenesis of $\mathrm{AD}, 36 \%$ of the patients exhibiting M. sympodialis colonization of the skin had specific IgE antibodies against human MnSOD [44]. These patients were skin test positive to M. sympodialis extract, to human recombinant MnSOD and to structurally related MnSODs. In an atopy patch test with patients suffering from severe atopic eczema, the application of human recombinant MnSOD on healthy skin elicited an eczematous reaction [44]. The release of intracellular selfantigens as a consequence of inflammation processes causing tissue damage is also proposed to be involved in the pathogenesis of ABPA [88].

Asp $\mathrm{f} 8$, the acid ribosomal protein $\mathrm{P} 2$ from A. fumigatus, cross-reacts with its human homologue P2. In skin tests, a humoral autoimmune response to the human P2 protein was seen in ABPA patients and patients with severe $\mathrm{AD}[91]$. 


\section{Diagnosis of Fungal Allergy}

For decades, the diagnosis of mold allergy has based on the patient's history, and on in vivo (e.g. SPT, intradermal test or inhalation challenge) and in vitro tests (e.g. RAST, ELISA and Western blot). However, the accuracy and reliability of in vivo and in vitro assays is very highly dependent on the quality of the fungal extracts used. Unfortunately, the correlation of the results obtained with skin tests and serological tests is very poor. A direct comparison between in vitro and in vivo results is hampered by the fact that extracts immobilized on testing devices, e.g. ImmunoCAPs, are not available as SPT solution and vice versa.

The quality of crude extracts for diagnosis and therapy is very unsatisfactory in case of fungal extracts. Currently, the quality of mold extracts varies dramatically between commercial suppliers in Europe and the USA since no standardized extracts are available $[46,58,153]$. The reasons for the insufficient quality are manifold. On the one hand, crude extracts from ascomycota as well as basidiomycota were shown to vary considerably in their protein composition $[154,155]$. These problems are caused by strain variabilities [156] and batch-to-batch variations [10,74]. Additionally, mold extracts may be produced from mycelial cells and/or spores, which may vary in their protein pattern $[157,158]$. On the other hand, growth conditions, protein extraction methods and storage conditions are critical with respect to the quantity and even existence of individual allergens $[61,65,157]$. Finally, degradation of the extracted proteins may occur, too [159]. In case of A. alternata [160], different allergens had different optimal extraction times, whereas the composition of the extraction buffer did not significantly affect the quantity of allergens extracted (with the exception that a low $\mathrm{pH}$ which resulted in a low protein yield). The diagnosis of mold allergy is also hampered by the fact that patients might not be aware of the mostly perennial fungal exposure, thus molds may not be taken into account for medical history. Moreover, the panel of allergycausing molds exceeds by far the number of extracts that reasonably can be used in routine assessments [161].

To some extent, the problems with fungal extracts may be overcome by the use of recombinant allergens. The major advantages of recombinant proteins over crude fungal extracts are threefold. Firstly, the protein preparations are reproducible and can be standardized for biochemical and immunological tests, e.g. mass spectrometry, circular dichroism, inhibition ELISAs, determination of T-cell reactivity and histamine release assays, and thus will give a batch-to-batch consistency. Secondly, the production of large quantities of pure proteins is possible. Thirdly, using recombinant allergens, it is possible to differentiate among co-exposure, co-sensitization and crossreactivity. This differentiation is important since primary sensitizing molds have to be known for a successful immunotherapy. Although recombinant allergens have got major advantages, they also have some properties which have to be taken into account for their expression. A few allergens undergo secondary modifications such as glycosylation, phosphorylation, and $\mathrm{N}$ - and/or C-terminal processing. Although these modifications may not directly be involved in IgE binding, they nevertheless may have a large impact on the three-dimensional structure and thus on the formation of IgE epitopes of a given protein. Therefore, the choice of the expression system is very important. Routinely, bacterial systems such as Escherichia coli are employed, but since proteins may not be folded properly and eukaryotic posttranslational modifications are not accomplished, alternative eukaryotic systems like Pichia pastoris, S. cerevisiae, Yarrowia lipolytica, Baculovirus and tobacco plant may be used [162, 163]. The P. pastoris system, for example, has been used for the expression of Alt a 1, the major allergen of A. alternata [164].

In the last years, several diagnostic studies have proven the concept of a component-resolved allergy diagnosis instead of using crude extracts [165-169].

In order to use a high throughput test, an allergogram may be generated using a microarray format enabling a large number of allergens to be tested in duplicate or triplicate with a small amount of patient sera, in order to receive a profile of the patient's IgE reactivity pattern [170].

Since the total number of relevant IgE-reactive allergens in molds is mostly higher than in pollens or foodstuff, a panel of recombinant allergens may be necessary in order to cover the patients' allergen profile. Major allergens of all fungal phyla like Alt a $1[48,171]$, Cla h 8 [49], Asp f 1 [78], Pen n 18 [106], Mala f 6 [131], Mala s 11 [133] and Psi c 2 [136] have been described. These major allergens combined with minor allergens are promising candidate molecules for molecular-based, patient-tailored immunotherapy.

In the last years, the first diagnostic studies have compared recombinant fungal allergens and crude mold extracts with respect to their negative and positive predictability of mold sensitization. In case of $A$. alternata two clinical studies were performed $[54,58]$ in which two allergens (Alt a 6 and Alt a 1) were promising candidate 
molecules. For A. fumigatus, a large number of allergens have been published. Since A. fumigatus is particularly known for its broad spectrum of human disorders, some groups aimed to find a link between a given disease and the patients' reactivity pattern to individual recombinant allergens. Hemmann et al. [89] and Kurup et al. [90] showed that individual recombinant allergens can be used to discriminate between ABPA (Asp f 2, Asp f 4 and Asp f 6) and fungal allergy (Asp f 1 and Asp f 3).

\section{Therapy of Fungal Allergy}

Specific immunotherapy is defined as the repeated administration of increasing doses of an allergen extract. For successful treatment, effective therapeutic doses are required, which often cannot be reached, especially in the case of mold allergy, since side effects due to a large number of non-allergenic components may occur. Several drawbacks have been ascribed to the use of crude protein extract. Since protein extracts contain a vast number of allergenic and non-allergenic components, in the course of immunotherapy a patient might develop IgE antibodies against additional components present in crude extracts, as was shown in case of specific immunotherapy of grass- and birch pollen-allergic patients using crude extracts $[172,173]$.

Immunotherapy with fungal extracts is possible, but in most countries not recommended because of problems with the standardization of extracts (see also Diagnosis of Fungal Allergy) [174] and the frequent occurrence of side effects [175]. Additionally, the use of fungal extracts for immunotherapy is hampered by the vast number of fungal species and the lack of knowledge on the degree of exposure to many molds. In the last years, only very few studies reporting a moderate reduction in symptoms have been conducted $[25,175,176]$. In a high-dose (maximal dose of 100,000 biological units), placebo-controlled, double-blind study [177], $81 \%$ of the C. herbarum-allergic patients hyposensitized with $C$. herbarum extract improved their clinical symptoms, whereas $19 \%$ showed a deterioration in their symptoms. In a 3-year clinical study including 79 children with asthma and rhinitis showing Alternaria sensitization, Cantani et al. [178] reported a successful immunotherapy (doses were higher than 80,000 protein nitrogen units) in $80 \%$ of their children.

Using a defined panel of allergenic molecules instead of crude extracts, a patient-tailored immunotherapy may be a future aim.

\section{Conclusions}

Taken together, a large number of fungal allergens have been isolated and characterized in the last years. Some of them have already been tested in clinical trials, demonstrating their benefit in the diagnosis of mold allergy $[54,58]$ and other fungal diseases such as ABPA [89, 90]. It has been shown that the specificity of recombinant allergens in serology and skin tests is clearly superior to the specificity obtained with commercial extracts [165].

Nevertheless, there is still a long way to go until immunotherapy of mold allergy will be safe and successful.

\section{Acknowledgement}

This work was supported by project S8812-MED given to B. Simon-Nobbe and M. Breitenbach by the Austrian Science Fund (FWF).

\section{References}

1 De Hoog GS, Guarro J, Gene J, Figueras MJ: Atlas of Clinical Fungi, ed 2. Utrecht, Centraalbureau voor Schimmelcultures, 2000.

-2 Kauffman HF, Tomee JF, van der WerfTS, de Monchy JG, Koeter GK: Review of fungusinduced asthmatic reactions. Am J Respir Crit Care Med 1995;151:2109-2115, discussion 2116

3 Bush RK, Portnoy JM, Saxon A, Terr AI, Wood RA: The medical effects of mold exposure. J Allergy Clin Immunol 2006;117:326333.
4 Kauffman HF, Tomee JF, van de Riet MA, Timmerman AJ, Borger P: Protease-dependent activation of epithelial cells by fungal allergens leads to morphologic changes and cytokine production. J Allergy Clin Immunol 2000;105:1185-1193.

5 Fischer G, Schwalbe R, Moller M, Ostrowski $\mathrm{R}$, Dott W: Species-specific production of microbial volatile organic compounds (MVOC) by airborne fungi from a compost facility. Chemosphere 1999;39:795-810.

6 Ingold CT, Hudson HJ: The Biology of Fungi, ed 6, revised. London, Chapman \& Hall, 1993.
7 Lacey L: The aerobiology of conidial fungi; in Cole GT, Kendrick B (eds): Biology of Conidial Fungi. New York, Academic Press, 1981, pp 123-128.

-8 D'Amato G, Spieksma FT: Aerobiologic and clinical aspects of mould allergy in Europe. Allergy 1995;50:870-877.

-9 Burge HA: Airborne allergenic fungi classification, nomenclature, and distribution. Immunol Allergy Clin North Am 1989;9: 307-319.

10 Burge HA: Fungus allergens. Clin Rev Allergy 1985;3:319-329. 
11 Dharmage S, Bailey M, Raven J, Mitakakis T, Thien F, Forbes A, Guest D, Abramson M, Walters EH: Prevalence and residential determinants of fungi within homes in Melbourne, Australia. Clin Exp Allergy 1999;29: 1481-1489.

12 Nevalainen A, Rautiala S, Hyvarinen A, Reponen T, Husman T, Kalliokoski P: Exposure to fungal spores in mouldy houses: effect of remedial work; in Agashe SN (ed): Recent Trends in Aerobiology, Allergy and Immunology. New Delhi, Oxford \& IBH, 1994, pp 99-107.

13 Gravesen S, Nielsen PA, Iversen R, Nielsen KF: Microfungal contamination of damp buildings - examples of risk constructions and risk materials. Environ Health Perspect 1999;107(suppl 3):505-508.

14 Kurup VP: Fungal Allergy; in Arora N (ed): Handbook of Fungal Biotechnology. New York, Dekker, 2003, pp 515-525.

15 Brummund W, Kurup VP, Harris GJ, Duncavage JA, Arkins JA: Allergic sino-orbital mycosis. A clinical and immunologic study. JAMA 1986;256:3249-3253.

-16 O’Brien IM, Bull J, Creamer B, Sepulveda R, Harries M, Burge PS, Pepys J: Asthma and extrinsic allergic alveolitis due to Merulius lacrymans. Clin Allergy 1978;8:535-542.

17 Sastre J, Ibanez MD, Lopez M, Lehrer SB: Respiratory and immunological reactions among Shiitake (Lentinus edodes) mushroom workers. Clin Exp Allergy 1990;20:1319.

18 Bhatnagar D, Yu J, Ehrlich KC: Toxins of filamentous fungi. Chem Immunol 2002;81: 167-206.

19 Samson RA: Mycotoxins: a mycologist's perspective. J Med Vet Mycol 1992;30(suppl 1): 9-18.

-20 Tariq SM, Matthews SM, Stevens M, Hakim EA: Sensitization to Alternaria and Cladosporium by the age of 4 years. Clin Exp Allergy 1996;26:794-798.

-21 Salvaggio J, Aukrust L: Postgraduate course presentations. Mold-induced asthma. J Allergy Clin Immunol 1981;68:327-346.

$\checkmark 22$ Corey JP, Kaiseruddin S, Gungor A: Prevalence of mold-specific immunoglobulins in a Midwestern allergy practice. Otolaryngol Head Neck Surg 1997;117:516-520.

23 Lopez M, Salvaggio JE: Mold-sensitive asthma. Clin Rev Allergy 1985;3:183-196.

24 Hsieh KH, Shen JJ: Prevalence of childhood asthma in Taipei, Taiwan, and other Asian Pacific countries. J Asthma 1988;25:73-82.

25 Horst M, Hejjaoui A, Horst V, Michel FB, Bousquet J: Double-blind, placebo-controlled rush immunotherapy with a standardized Alternaria extract. J Allergy Clin Immunol 1990;85:460-472.

-26 Zureik M, Neukirch C, Leynaert B, Liard R, Bousquet J, Neukirch F: Sensitisation to airborne moulds and severity of asthma: cross sectional study from European Community respiratory health survey. BMJ 2002;325: 411-414.
27 Denning DW, O’Driscoll BR, Hogaboam CM, Bowyer P, Niven RM: The link between fungi and severe asthma: a summary of the evidence. Eur Respir J 2006;27:615-626.

-28 Targonski PV, Persky VW, Ramekrishnan V: Effect of environmental molds on risk of death from asthma during the pollen season. J Allergy Clin Immunol 1995;95:955-961.

29 Halonen M, Stern DA, Wright AL, Taussig LM, Martinez FD: Alternaria as a major allergen for asthma in children raised in a desert environment. Am J Respir Crit Care Med 1997;155:1356-1361.

-30 Nelson HS, Szefler SJ, Jacobs J, Huss K, Shapiro G, Sternberg AL: The relationships among environmental allergen sensitization, allergen exposure, pulmonary function, and bronchial hyperresponsiveness in the Childhood Asthma Management Program. J Allergy Clin Immunol 1999;104: 775-785.

31 Peat JK, Tovey E, Mellis CM, Leeder SR, Woolcock AJ: Importance of house dust mite and Alternaria allergens in childhood asthma: an epidemiological study in two climatic regions of Australia. Clin Exp Allergy 1993;23:812-820.

32 Black PN, Udy AA, Brodie SM: Sensitivity to fungal allergens is a risk factor for life-threatening asthma. Allergy 2000;55:501-504.

33 O’Driscoll BR, Hopkinson LC, Denning DW: Mold sensitization is common amongst patients with severe asthma requiring multiple hospital admissions. BMC Pulm Med 2005;5:4

34 Reed CE: What we do and do not know about mold allergy and asthma. J Allergy Clin Immunol 1985;76:773-775.

35 Dales RE, Cakmaks, JudekS, Dann T, Coates F, Brook JR, Burnett RT: The role of fungal spores in thunderstorm asthma. Chest 2003; 123:745-750.

36 O’Hollaren MT, Yunginger JW, Offord KP, Somers MJ, O'Connell EJ, Ballard DJ, Sachs MI: Exposure to an aeroallergen as a possible precipitating factor in respiratory arrest in young patients with asthma. $\mathrm{N}$ Engl J Med 1991;324:359-363.

37 Bush RK, Prochnau JJ: Alternaria-induced asthma. J Allergy Clin Immunol 2004;113: $227-234$

-38 Neukirch C, Henry C, Leynaert B, Liard R, Bousquet J, Neukirch F: Is sensitization to Alternaria alternata a risk factor for severe asthma? A population-based study. J Allergy Clin Immunol 1999;103:709-711.

-39 Niedoszytko M, Chelminska M, Jassem E, Czestochowska E: Association between sensitization to Aureobasidium pullulans (Pullularia sp) and severity of asthma. Ann Allergy Asthma Immunol 2007;98:153-156.

40 Leung DY: Atopic dermatitis: new insights and opportunities for therapeutic intervention. J Allergy Clin Immunol 2000;105:860876.
-41 Kieffer M, Bergbrant IM, Faergemann J, Jemec GB, Ottevanger V, Stahl Skov P, Svejgaard E: Immune reactions to Pityrosporum ovale in adult patients with atopic and seborrheic dermatitis. J Am Acad Dermatol 1990; 22:739-742.

42 Gfesser M, Abeck D, Rugemer J, Schreiner V, Stab F, Disch R, Ring J: The early phase of epidermal barrier regeneration is faster in patients with atopic eczema. Dermatology 1997; 195:332-336.

43 Walker C, Kagi MK, Ingold P, Braun P, Blaser $\mathrm{K}$, Bruijnzeel-Koomen CA, Wuthrich B: Atopic dermatitis: correlation of peripheral blood $\mathrm{T}$ cell activation, eosinophilia and serum factors with clinical severity. Clin Exp Allergy 1993;23:145-153.

44 Schmid-Grendelmeier P, Fluckiger S, Disch R, Trautmann A, Wuthrich B, Blaser K, Scheynius A, Crameri R: IgE-mediated and T cell-mediated autoimmunity against manganese superoxide dismutase in atopic dermatitis. J Allergy Clin Immunol 2005;115: 1068-1075.

45 Kortekangas-Savolainen O, Lammintausta K, Kalimo K: Skin prick test reactions to brewer's yeast (Saccharomyces cerevisiae) in adult atopic dermatitis patients. Allergy 1993;48:147-150.

-46 Mari A, Schneider P, Wally V, Breitenbach M, Simon-Nobbe B: Sensitization to fungi: epidemiology, comparative skin tests, and IgE reactivity of fungal extracts. Clin Exp Allergy 2003;33:1429-1438.

-47 Eggleston PA, Rosenstreich D, Lynn H, Gergen $\mathrm{P}$, Baker D, Kattan M, Mortimer KM, Mitchell H, Ownby D, Slavin R, Malveaux F: Relationship of indoor allergen exposure to skin test sensitivity in inner-city children with asthma. J Allergy Clin Immunol 1998; 102:563-570.

48 Achatz G, Oberkofler H, Lechenauer E, Simon B, Unger A, Kandler D, Ebner C, Prillinger $\mathrm{H}$, Kraft D, Breitenbach M: Molecular cloning of major and minor allergens of Alternaria alternata and Cladosporium herbarum. Mol Immunol 1995;32:213-227.

49 Simon-Nobbe B, Denk U, Schneider PB, Radauer C, Teige M, Crameri R, Hawranek T, Lang R, Richter K, Schmid-Grendelmeier P, Nobbe S, Hartl A, Breitenbach M: NADPdependent mannitol dehydrogenase, a major allergen of Cladosporium herbarum. J Biol Chem 2006;281:16354-16360.

50 Schneider PB, Denk U, Breitenbach M, Richter K, Schmid-Grendelmeier P, Nobbe S, Himly M, Mari A, Ebner C, Simon-Nobbe B: Alternaria alternata NADP-dependent mannitol dehydrogenase is an important fungal allergen. Clin Exp Allergy 2006;36:15131524

51 Breitenbach M, Simon B, Probst G, Oberkofler H, Ferreira F, Briza P, Achatz G, Unger A, Ebner C, Kraft D, Hirschwehr R: Enolases are highly conserved fungal allergens. Int Arch Allergy Immunol 1997;113:114117. 
52 Simon-Nobbe B, Probst G, Kajava AV, Oberkofler H, Susani M, Crameri R, Ferreira F, Ebner C, Breitenbach M: IgE-binding epitopes of enolases, a class of highly conserved fungal allergens. J Allergy Clin Immunol 2000;106:887-895.

53 Zhang L, Muradia G, De Vouge MW, Rode H, Vijay HM: An allergenic polypeptide representing a variable region of hsp 70 cloned from a cDNA library of Cladosporium herbarum. Clin Exp Allergy 1996;26:88-95.

54 Asturias JA, Ibarrola I, Ferrer A, Andreu C, Lopez-Pascual E, Quiralte J, Florido F, Martinez A: Diagnosis of Alternaria alternata sensitization with natural and recombinant Alt a 1 allergens. J Allergy Clin Immunol 2005;115:1210-1217.

-55 Curran IH, Young NM, Burton M, Vijay HM: Purification and characterization of Alt a-29 from Alternaria alternata. Int Arch Allergy Immunol 1993;102:267-275.

-56 De Vouge MW, Thaker AJ, Zhang L, Muradia G, Rode H, Vijay HM: Molecular cloning of IgE-binding fragments of Alternaria alternata allergens. Int Arch Allergy Immunol 1998;116:261-268.

-57 Zhang L, Curran IH, Muradia G, De Vouge MW, Rode H, Vijay HM: N-terminus of a major allergen, Alt a I, of Alternaria alternata defined to be an epitope. Int Arch Allergy Immunol 1995;108:254-259.

- 58 Unger A, Stoger P, Simon-Nobbe B, Susani M, Crameri R, Ebner C, Hintner H, Breitenbach M: Clinical testing of recombinant allergens of the mold Alternaria alternata. Int Arch Allergy Immunol 1999;118:220-221.

-59 Bush RK, Sanchez H, Geisler D: Molecular cloning of a major Alternaria alternata allergen, rAlt a 2. J Allergy Clin Immunol 1999; 104:665-671.

60 Kurup VP, Vijay HM, Kumar V, Castillo L, Elms N: IgE binding synthetic peptides of Alt a 1 , a major allergen of Alternaria alternata. Peptides 2003;24:179-185.

61 Breitenbach M, Simon-Nobbe B: The allergens of Cladosporium herbarum and Alternaria alternata. Chem Immunol 2002;81:48-72.

62 Breitenbach M, Simon Nobbe B, Denk U, Schneider P, Richter K, Teige M, Radauer C, Ebner C, Nobbe S, Schmid-Grendelmeier P, Crameri R: Cloning, expression, characterization, and skin prick testing of NADPHdependent mannitol dehydrogenase. A new major allergen of Cladosporium herbarum; in Lowenstein H, Bienenstock J, Ring J (eds): From Genes to Phenotypes - The Basis of Future Allergy Managment. Cambridge, Hogrefe \& Huber, 2005, pp 75-77.

63 Chou H, Tam MF, Lee SS, Tai HY, Chang CY, Chou CT, Shen HD: A vacuolar serine protease (Rho $\mathrm{m} \mathrm{2}$ ) is a major allergen of Rhodotorula mucilaginosa and belongs to a class of highly conserved pan-fungal allergens. Int Arch Allergy Immunol 2005;138:134-141.
64 Simon-Nobbe B, Kodzius R, Kajava AV, Ferreira F, Kungl A, Achatz G, Crameri R, Ebner C, Breitenbach M: Structure of an IgE-binding peptide from fungal enolases. Int Arch Allergy Immunol 2001;124:93-94.

65 Horner WE, Helbling A, Salvaggio JE, Lehrer SB: Fungal allergens. Clin Microbiol Rev 1995;8:161-179.

66 Terr AI: Are indoor molds causing a new disease? J Allergy Clin Immunol 2004;113:221226.

67 Kurup VP, Shen HD, Banerjee B: Respiratory fungal allergy. Microbes Infect 2000;2:11011110.

68 Kurup VP, Banerjee B: Fungal allergens and peptide epitopes. Peptides 2000;21:589-599.

69 Vijay HM, Kurup VP: Fungal allergens. Clin Allergy Immunol 2004;18:223-249.

70 Crameri R, Blaser K: Cloning Aspergillus fumigatus allergens by the pJuFo filamentous phage display system. Int Arch Allergy Immunol 1996;110:41-45.

71 Arruda LK, Mann BJ, Chapman MD: Selective expression of a major allergen and cytotoxin, Asp f I, in Aspergillus fumigatus. Implications for the immunopathogenesis of Aspergillus-related diseases. J Immunol 1992;149:3354-3359.

72 Banerjee B, Kurup VP, Greenberger PA, Hoff man DR, Nair DS, Fink JN: Purification of a major allergen, Asp f 2 binding to IgE in allergic bronchopulmonary aspergillosis, from culture filtrate of Aspergillus fumigatus. J Allergy Clin Immunol 1997;99:821-827.

73 Crameri R: Recombinant Aspergillus fumigatus allergens: from the nucleotide sequences to clinical applications. Int Arch Allergy Immunol 1998;115:99-114.

74 Vailes L, Sridhara S, Cromwell O, Weber B, Breitenbach M, Chapman M: Quantitation of the major fungal allergens, Alt a 1 and Asp $\mathrm{f} 1$, in commercial allergenic products. $\mathrm{J} \mathrm{Al}$ lerg Clin Immunol 2001;107:641-646.

$>75$ Crameri R, Weichel M, Fluckiger S, Glaser AG, Rhyner C: Fungal allergies: a yet unsolved problem. Chem Immunol Allergy 2006;91:121-133.

76 Crameri R, Hemmann S, Mayer C, Appenzeller U, Blaser K: Molecular aspects and diagnostic value of fungal allergens (in German). Mycoses 1998;41:56-60.

77 Moser M, Crameri R, Menz G, Schneider T, Dudler T, Virchow C, Gmachl M, Blaser K, Suter M: Cloning and expression of recombinant Aspergillus fumigatus allergen I/a (rAsp f I/a) with IgE binding and type I skin test activity. J Immunol 1992;149:454-460.

78 Kurup VP, Banerjee B, Murali PS, Greenberger PA, Krishnan M, Hari V, Fink JN: Immunodominant peptide epitopes of allergen, Asp f 1 from the fungus Aspergillus fumigatus. Peptides 1998;19:1469-1477.

79 Moser M, Crameri R, Brust E, Suter M, Menz G: Diagnostic value of recombinant Aspergillus fumigatus allergen I/a for skin testing and serology. J Allergy Clin Immunol 1994; 93:1-11.
80 Chauhan B, Santiago L, Kirschmann DA, Hauptfeld V, Knutsen AP, Hutcheson PS, Woulfe SL, Slavin RG, Schwartz HJ, Bellone CJ: The association of HLA-DR alleles and T cell activation with allergic bronchopulmonary aspergillosis. J Immunol 1997;159: 4072-4076.

$>81$ Banerjee B, Greenberger PA, Fink JN, Kurup VP: Conformational and linear B-cell epitopes of Asp f 2, a major allergen of Aspergillus fumigatus, bind differently to immunoglobulin E antibody in the sera of allergic bronchopulmonary aspergillosis patients. Infect Immun 1999;67:2284-2291.

82 Tang B, Banerjee B, Greenberger PA, Fink JN, Kelly KJ, Kurup VP: Antibody binding of deletion mutants of Asp f2, the major Aspergillus fumigatus allergen. Biochem Biophys Res Commun 2000;270:1128-1135.

83 Rathore VB, Johnson B, Fink JN, Kelly KJ, Greenberger PA, Kurup VP: T cell proliferation and cytokine secretion to T cell epitopes of Asp f 2 in ABPA patients. Clin Immunol 2001;100:228-235.

84 Hemmann S, Blaser K, Crameri R: Allergens of Aspergillus fumigatus and Candida boidinii share IgE-binding epitopes. Am J Respir Crit Care Med 1997;156:1956-1962.

85 Hemmann S, Ismail C, Blaser K, Menz G, Crameri R: Skin-test reactivity and isotypespecific immune responses to recombinant Asp f 3, a major allergen of Aspergillus fumigatus. Clin Exp Allergy 1998;28:860-867.

-86 Ramachandran H, Jayaraman V, Banerjee B, Greenberger PA, Kelly KJ, Fink JN, Kurup VP: IgE binding conformational epitopes of Asp f 3, a major allergen of Aspergillus fumigatus. Clin Immunol 2002;103:324-333.

87 Ramachandran H, Banerjee B, Greenberger PA, Kelly KJ, Fink JN, Kurup VP: Role of Cterminal cysteine residues of Aspergillus fumigatus allergen Asp f 4 in immunoglobulin E binding. Clin Diagn Lab Immunol 2004; 11:261-265.

88 Crameri R, Faith A, Hemmann S, Jaussi R, Ismail C, Menz G, Blaser K: Humoral and cell-mediated autoimmunity in allergy to Aspergillus fumigatus. J Exp Med 1996;184: 265-270.

89 Hemmann S, Menz G, Ismail C, Blaser K, Crameri R: Skin test reactivity to 2 recombinant Aspergillus fumigatus allergens in $\mathrm{A}$ fumigatus-sensitized asthmatic subjects allows diagnostic separation of allergic bronchopulmonary aspergillosis from fungal sensitization. J Allergy Clin Immunol 1999; 104:601-607.

>0 Kurup VP, Banerjee B, Hemmann S, Greenberger PA, Blaser K, Crameri R: Selected recombinant Aspergillus fumigatus allergens bind specifically to IgE in ABPA. Clin Exp Allergy 2000;30:988-993. 
91 Mayer C, Appenzeller U, Seelbach H, Achatz G, Oberkofler H, Breitenbach M, Blaser K, Crameri R: Humoral and cell-mediated autoimmune reactions to human acidic ribosomal $\mathrm{P} 2$ protein in individuals sensitized to Aspergillus fumigatus P2 protein. J Exp Med 1999; 189:1507-1512.

\$2 Kumar A, Reddy LV, Sochanik A, Kurup VP: Isolation and characterization of a recombinant heat shock protein of Aspergillus fumigatus. J Allergy Clin Immunol 1993;91: 1024-1030.

93 Shen HD, Tam MF, Chou H, Han SH: The importance of serine proteinases as aeroallergens associated with asthma. Int Arch Allergy Immunol 1999;119:259-264.

$\$ 94$ Shen HD, Lin WL, Tam MF, Wang SR, Tzean SS, Huang MH, Han SH: Characterization of allergens from Penicillium oxalicum and P. notatum by immunoblotting and $\mathrm{N}$-terminal amino acid sequence analysis. Clin Exp Allergy 1999;29:642-651.

$\$ 95$ Chow LP, Liu SL, Yu CJ, Liao HK, Tsai JJ, Tang TK: Identification and expression of an allergen Asp f 13 from Aspergillus fumigatus and epitope mapping using human $\mathrm{IgE}$ antibodies and rabbit polyclonal antibodies. Biochem J 2000;346:423-431.

96 Lai HYL, Tam MF, Tang RB, Chou H, Chang CY, Tsai JJ, Shen HS: cDNA cloning and immunological characterization of a newly identified enolase allergen from Penicillium citrinum and Aspergillus fumigatus. Int Arch Allergy Immunol 2002;127: 181-190.

-97 Bowyer P, Denning DW: Genomic analysis of allergen genes in Aspergillus spp: the relevance of genomics to everyday research. Med Mycol 2007;45:17-26.

$\$ 98$ Wei DL, Jong SC, Shen HD: Indoor airborne Penicillium species in Taiwan. Curr Microbiol 1993;26:137-140.

99 Muilenberg M, Burge HA, Sweet T, Solomon W: Penicillium species in and out of doors in Topeka, KS. J Allergy Clin Immunol 1990;85:247.

100 Licorish K, Novey HS, Kozak P, Fairshter RD, Wilson AF: Role of Alternaria and Penicillium spores in the pathogenesis of asthma. J Allergy Clin Immunol 1985;76:819825.

101 Hsieh KH: A study of intracutaneous skin tests and radioallergosorbent tests on 1,000 asthmatic children in Taiwan. Asian Pac J Allergy Immunol 1984;2:56-60.

102 Chow LP, Su NY, Yu CJ, Chiang BL, Shen HD: Identification and expression of Pen $c$ 2, a novel allergen from Penicillium citrinum. Biochem J 1999;341:51-59.

- 103 Shen HD, Au LC, Lin WL, Liaw SF, Tsai JJ, Han SH: Molecular cloning and expression of a Penicillium citrinum allergen with sequence homology and antigenic crossreactivity to a hsp 70 human heat shock protein. Clin Exp Allergy 1997;27:682-690.
104 Shen HD, Wang CW, Lin WL, Lai HY, Tam MF, Chou H, Wang SR, Han SH: cDNA cloning and immunologic characterization of Pen o 18, the vacuolar serine protease major allergen of Penicillium oxalicum. J Lab Clin Med 2001;137:115-124.

105 Lai HY, Tam MF, Chou H, Lee SS, Tai HY, Shen HD: Molecular and structural analysis of immunoglobulin E-binding epitopes of Pen ch 13, an alkaline serine protease major allergen from Penicillium chrysogenum. Clin Exp Allergy 2004;34:19261933.

106 Shen HD, Chou H, Tam MF, Chang CY, Lai HY, Wang SR: Molecular and immunological characterization of Pen ch 18 , the vacuolar serine protease major allergen of Penicillium chrysogenum. Allergy 2003;58: 993-1002.

107 Yu CJ, Chen YM, Su SN, Forouhar F, Lee $\mathrm{SH}$, Chow LP: Molecular and immunological characterization and IgE epitope mapping of Pen n 18, a major allergen of Penicillium notatum. Biochem J 2002;363: 707-715.

108 Shen HD, Wang CW, Chou H, Lin WL, Tam MF, Huang MH, Kuo ML, Wang SR, Han $\mathrm{SH}$ : Complementary DNA cloning and immunologic characterization of a new Penicillium citrinum allergen (Pen c 3). J Allergy Clin Immunol 2000;105:827-833.

109 Sevinc MS, Kumar V, Abebe M, Casley WL, Vijay HM: Isolation and characterization of a cDNA clone encoding one IgE-binding fragment of Penicillium brevicompactum. Int Arch Allergy Immunol 2005;138:1220.

110 Tang RB, Chen YS, Chou H, Lee SS, Tai HY, Shen HD: cDNA cloning and immunologic characterization of a novel EF-1 $\beta$ allergen from Penicillium citrinum. Allergy 2005; 60:366-371.

111 Akiyama K, Shida T, Yasueda H, Mita H, Yanagihara Y, Hasegawa M, Maeda Y, Yamamoto T, Takesako K, Yamaguchi H: Allergenicity of acid protease secreted by Candida albicans. Allergy 1996;51:887892.

112 Martinez JP, Gil ML, Lopez-Ribot JL, Chaffin WL: Serologic response to cell wall mannoproteins and proteins of Candida albicans. Clin Microbiol Rev 1998;11:121141.

-113 Ito K, Ishiguro A, Kanbe T, Tanaka K, Torii $\mathrm{S}$ : Characterization of IgE-binding epitopes on Candida albicans enolase. Clin Exp Allergy 1995;25:529-535.

-114 Eroles P, Sentandreu M, Elorza MV, Sentandreu R: The highly immunogenic enolase and Hsp70p are adventitious Candida albicans cell wall proteins. Microbiology 1997; 143(Pt 2):313-320.

- 115 Burge HA, Solomon WR, Muilenberg ML: Evaluation of indoor plantings as allergen exposure sources. J Allergy Clin Immunol 1982;70:101-108.
116 Levetin E: Studies on airborne basidiospores. Aerobiologia 1990;6:177-180.

117 Luo W: Deposition of large particles in the nose and mouth. Grana 1991;30:79-81.

118 Roncarolo D, Minale P, Mistrello G, Voltolini S, Falagiani P: Food allergy to Boletus edulis. J Allergy Clin Immunol 1998; 101: 850-851.

119 Levy AM, Kita H, Phillips SF, Schkade PA, Dyer PD, Gleich GJ, Dubravec VA: Eosinophilia and gastrointestinal symptoms after ingestion of shiitake mushrooms. J Allergy Clin Immunol 1998;101:613-620.

120 Epton MJ, Martin IR, Graham P, Healy PE, Smith H, Balasubramaniam R, Harvey IC, Fountain DW, Hedley J, Town GI: Climate and aeroallergen levels in asthma: a 12 month prospective study. Thorax 1997;52: 528-534.

121 Brander KA, Borbely P, Crameri R, Pichler WJ, Helbling A: IgE-binding proliferative responses and skin test reactivity to Cop c 1 , the first recombinant allergen from the basidiomycete Coprinus comatus. J Allergy Clin Immunol 1999;104:630-636.

122 Lehrer SB, Hughes JM, Altman LC, Bousquet J, Davies RJ, Gell L, Li J, Lopez M, Malling HJ, Mathison DA, et al: Prevalence of basidiomycete allergy in the USA and Europe and its relationship to allergic respiratory symptoms. Allergy 1994;49:460465.

123 Helbling A, Gayer F, Pichler WJ, Brander KA: Mushroom (Basidiomycete) allergy: diagnosis established by skin test and nasal challenge. J Allergy Clin Immunol 1998; 102:853-858.

124 Helbling A, Brander KA, Horner WE, Lehrer SB: Allergy to basidiomycetes. Chem Immunol 2002;81:28-47.

125 Faergemann J, Fredriksson T: Age incidence of Pityrosporum orbiculare on human skin. Acta Derm Venereol 1980;60: 531-533.

126 Faergemann J, Aly R, Maibach HI: Quantitative variations in distribution of Pityrosporum orbiculare on clinically normal skin. Acta Derm Venereol 1983;63:346348.

127 Lintu P, Savolainen J, Kalimo K: IgE antibodies to protein and mannan antigens of Pityrosporum ovale in atopic dermatitis patients. Clin Exp Allergy 1997;27:87-95.

128 Johansson S, Karlstrom K: IgE-binding components in Pityrosporum orbiculare identified by an immunoblotting technique. Acta Derm Venereol 1991;71:11-16.

129 Garrard LJ, Goodman JM: Two genes encode the major membrane-associated protein of methanol-induced peroxisomes from Candida boidinii. J Biol Chem 1989; 264:13929-13937. 
-130 Yasueda H, Hashida-Okado T, Saito A, Uchida K, Kuroda M, Onishi Y, Takahashi K, Yamaguchi H, Takesako K, Akiyama K: Identification and cloning of two novel allergens from the lipophilic yeast, Malassezia furfur. Biochem Biophys Res Commun 1998;248:240-244.

-131 Lindborg M, Magnusson CG, Zargari A, Schmidt M, Scheynius A, Crameri R, Whitley P: Selective cloning of allergens from the skin colonizing yeast Malassezia furfur by phage surface display technology. J Invest Dermatol 1999;113:156-161.

- 132 Onishi Y, Kuroda M, Yasueda H, Saito A, Sono-Koyama E, Tunasawa S, HashidaOkado T, Yagihara T, Uchida K, Yamaguchi H, Akiyama K, Kato I, Takesako K: Twodimensional electrophoresis of Malassezia allergens for atopic dermatitis and isolation of Mal f 4 homologs with mitochondrial malate dehydrogenase. Eur J Biochem 1999; 261:148-154.

-133 Andersson A, Rasool O, Schmidt M, Kodzius R, Fluckiger S, Zargari A, Crameri $\mathrm{R}$, Scheynius A: Cloning, expression and characterization of two new IgE-binding proteins from the yeast Malassezia sympodialis with sequence similarities to heat shock proteins and manganese superoxide dismutase. Eur J Biochem 2004;271:18851894.

-134 Nierman WC, Pain A, Anderson MJ, et al: Genomic sequence of the pathogenic and allergenic filamentous fungus Aspergillus fumigatus. Nature 2005;438:1151-1156.

$\checkmark 135$ Helbling A, Horner WE, Lehrer SB: Comparison of Psilocybe cubensis spore and mycelium allergens. J Allergy Clin Immunol 1993;91:1059-1066.

-136 Horner WE, Reese G, Lehrer SB: Identification of the allergen Psi c 2 from the basidiomycete Psilocybe cubensis as a fungal cyclophilin. Int Arch Allergy Immunol 1995; 107:298-300.

-137 Chang CY, Chou H, Tam MF, Tang RB, Lai HY, Shen HD: Characterization of enolase allergen from Rhodotorula mucilaginosa. J Biomed Sci 2002;9:645-655.

-138 Aalberse RC, Akkerdaas J, van Ree R: Cross-reactivity of IgE antibodies to allergens. Allergy 2001;56:478-490.

139 Aalberse RC: Structural biology of allergens. J Allergy Clin Immunol 2000;106: 228-238.

$\checkmark 140$ O’Neil CE, Horner WE, Reed MA, Lopez M, Lehrer SB: Evaluation of Basidiomycete and Deuteromycete (Fungi Imperfecti) extracts for shared allergenic determinants. Clin Exp Allergy 1990;20:533-538.

-141 Saenz-de-Santamaria M, Postigo I, Gutierrez-Rodriguez A, Cardona G, Guisantes JA, Asturias J, Martinez J: The major allergen of Alternaria alternata (Alt a 1) is expressed in other members of the Pleosporaceae family. Mycoses 2006;49:91-95.
142 Lin WL, Chou H, Tam MF, Huang MH, Han SH, Shen HD: Production and characterization of monoclonal antibodies to serine proteinase allergens in Penicillium and Aspergillus species. Clin Exp Allergy 2000; 30:1653-1662.

143 Simon-Nobbe B, Pöll V, Wally V, Shen HD, Lottspeich F, Hawranek T, Lang R, Hemmer W, Jarisch R, Breitenbach M: Vacuolar serine proteases from Cladosporium herbarum and Alternaria alternata, submitted.

144 Gupta R, Singh BP, Sridhara S, Gaur SN, Kumar R, Chaudhary VK, Arora N: Allergenic cross-reactivity of Curvularia lunata with other airborne fungal species. Allergy 2002;57:636-640.

145 Karkkainen M, Raunio P, Rautiainen J, Auriola S, Hinke K, Pasanen AL: Partial amino acid sequence of a cellulase-like component with IgE-binding properties from Stachybotrys chartarum. Int Arch Allergy Immunol 2004;133:136-144.

146 Wagner S, Breiteneder H, Simon-Nobbe B, Susani M, Krebitz M, Niggemann B, Brehler R, Scheiner O, Hoffmann-Sommergruber K: Hev b 9, an enolase and a new crossreactive allergen from Hevea latex and molds. Purification, characterization, cloning and expression. Eur J Biochem 2000; 267:7006-7014.

147 Shankar J, Gupta PD, Sridhara S, Singh BP, Gaur SN, Arora N: Immunobiochemical analysis of cross-reactive glutathione-Stransferase allergen from different fungal sources. Immunol Invest 2005;34:37-51.

148 Fluckiger S, Scapozza L, Mayer C, Blaser K, Folkers G, Crameri R: Immunological and structural analysis of IgE-mediated crossreactivity between manganese superoxide dismutases. Int Arch Allergy Immunol 2002;128:292-303.

149 Wagner S, Sowka S, Mayer C, Crameri R, Focke M, Kurup VP, Scheiner O, Breiteneder H: Identification of a Hevea brasiliensis latex manganese superoxide dismutase (Hev b 10) as a cross-reactive allergen. Int Arch Allergy Immunol 2001;125:120-127.

150 Glaser AG, Limacher A, Fluckiger S, Scheynius A, Scapozza L, Crameri R: Anal$y$ sis of the cross-reactivity and of the $1.5 \mathrm{~A}$ crystal structure of the Malassezia sympodialis Mala s 6 allergen, a member of the cyclophilin pan-allergen family. Biochem J 2006;396:41-49.

151 Appenzeller U, Meyer C, Menz G, Blaser K, Crameri R: IgE-mediated reactions to autoantigens in allergic diseases. Int Arch Allergy Immunol 1999;118:193-196.

152 Weichel M, Glaser AG, Ballmer-Weber BK, Schmid-Grendelmeier P, Crameri R: Wheat and maize thioredoxins: a novel cross-reactive cereal allergen family related to baker's asthma. J Allergy Clin Immunol 2006;117: 676-681.
153 Esch RE: Manufacturing and standardizing fungal allergen products. J Allergy Clin Immunol 2004;113:210-215.

154 Aas K, Leegaard J, Aukrust L, Grimmer O: Immediate type hypersensitivity to common moulds. Comparison of different diagnostic materials. Allergy 1980;35:443451.

155 Portnoy J, Chapman J, Burge H, Muilenberg M, Solomon W: Epicoccum allergy: skin reaction patterns and spore/mycelium disparities recognized by IgG and IgE ELISA inhibition. Ann Allergy 1987;59:3943.

156 Steringer I, Aukrust L, Einarsson R: Variability of antigenicity/allergenicity in different strains of Alternaria alternata. Int Arch Allergy Appl Immunol 1987;84:190197.

157 Paris S, Fitting C, Ramirez E, Latge JP, David B: Comparison of different extraction methods of Alternaria allergens. J Allergy Clin Immunol 1990;85:941-948.

158 Hoffman DR, Kozak PP Jr, Gillman SA, Cummins LH, Gallup J: Isolation of spore specific allergens from Alternaria. Ann Allergy 1981;46:310-316.

159 Ferreira F, Wallner M, Thalhamer J: Customized antigens for desensitizing allergic patients. Adv Immunol 2004;84:79-129.

160 Portnoy J, Pacheco F, Ballam Y, Barnes C: The effect of time and extraction buffers on residual protein and allergen content of extracts derived from four strains of Alternaria. J Allergy Clin Immunol 1993;91: 930-938.

161 Green BJ, Sercombe JK, Tovey ER: Fungal fragments and undocumented conidia function as new aeroallergen sources. J Allergy Clin Immunol 2005;115:10431048.

162 Chapman MD, Smith AM, Vailes LD, Arruda LK, Dhanaraj V, Pomes A: Recombinant allergens for diagnosis and therapy of allergic disease. J Allergy Clin Immunol 2000;106:409-418.

163 Schmidt M, Hoffman DR: Expression systems for production of recombinant allergens. Int Arch Allergy Immunol 2002;128: 264-270.

164 De Vouge MW, Thaker AJ, Curran IH, Zhang L, Muradia G, Rode H, Vijay HM: Isolation and expression of a cDNA clone encoding an Alternaria alternata Alt a 1 subunit. Int Arch Allergy Immunol 1996; 111:385-395.

165 Schmid-Grendelmeier P, Crameri R: Recombinant allergens for skin testing. Int Arch Allergy Immunol 2001;125:96-111.

166 Ballmer-Weber BK, Scheurer S, Fritsche P, Enrique E, Cistero-Bahima A, Haase T, Wuthrich B: Component-resolved diagnosis with recombinant allergens in patients with cherry allergy. J Allergy Clin Immunol 2002;110:167-173. 
-167 Tresch S, Holzmann D, Baumann S, Blaser K, Wuthrich B, Crameri R, Schmid-Grendelmeier P: In vitro and in vivo allergenicity of recombinant Bet $\mathrm{v} 1$ compared to the reactivity of natural birch pollen extract. Clin Exp Allergy 2003;33:1153-1158.

168 Valenta R, Lidholm J, Niederberger V, Hayek B, Kraft D, Gronlund H: The recombinant allergen-based concept of component-resolved diagnostics and immunotherapy (CRD and CRIT). Clin Exp Allergy 1999;29:896-904.

169 Mari A: Skin test with a timothy grass (Phleum pratense) pollen extract vs. IgE to a timothy extract vs. IgE to $\mathrm{rPhl} \mathrm{p} 1, \mathrm{rPhl} \mathrm{p}$ 2, nPhl p 4, rPhl p 5, rPhl p 6, rPhl p 7, rPhl $\mathrm{p} 11$, and $\mathrm{rPhl} \mathrm{p}$ 12: epidemiological and diagnostic data. Clin Exp Allergy 2003;33: 43-51.

170 Hiller R, Laffer S, Harwanegg C, et al: Microarrayed allergen molecules: diagnostic gatekeepers for allergy treatment. FASEB J 2002;16:414-416.

- 171 Vailes LD, Perzanowski MS, Wheatley LM, Platts-Mills TA, Chapman MD: IgE and IgG antibody responses to recombinant Alt a 1 as a marker of sensitization to Alternaria in asthma and atopic dermatitis. Clin Exp Allergy 2001;31:1891-1895.

- 172 Ball T, Sperr WR, Valent P, Lidholm J, Spitzauer S, Ebner C, Kraft D, Valenta R: Induction of antibody responses to new $\mathrm{B}$ cell epitopes indicates vaccination character of allergen immunotherapy. Eur J Immunol 1999;29:2026-2036.

- 173 Moverare R, Elfman L, Vesterinen E, Metso T, Haahtela T: Development of new IgE specificities to allergenic components in birch pollen extract during specific immunotherapy studied with immunoblotting and Pharmacia CAP System. Allergy 2002; 57:423-430

174 Malling HJ: Immunotherapy for mold allergy. Clin Rev Allergy 1992;10:237-251

-175 Malling HJ, Dreborg S, Weeke B: Diagnosis and immunotherapy of mould allergy. V. Clinical efficacy and side effects of immunotherapy with Cladosporium herbarum. Allergy 1986;41:507-519.

- 176 Dreborg S, Agrell B, Foucard T, Kjellman NI, Koivikko A, Nilsson S: A double-blind, multicenter immunotherapy trial in children, using a purified and standardized Cladosporium herbarum preparation. I. Clinical results. Allergy 1986;41:131-140.

177 Malling HJ: Diagnosis and immunotherapy of mould allergy. With special reference to Cladosporium herbarum. Dan Med Bull 1990;37:12-22.

- 178 Cantani A, Businco E, Maglio A: Alternaria allergy: a three-year controlled study in children treated with immunotherapy. Allergol Immunopathol (Madr) 1988;16:1-4.
179 Ezeamuzie CI, Al-Ali S, Khan M, Hijazi Z, Dowaisan A, Thomson MS, Georgi J: IgEmediated sensitization to mould allergens among patients with allergic respiratory diseases in a desert environment. Int Arch Allergy Immunol 2000;121:300-307.

180 Gergen PJ, Turkeltaub PC, Kovar MG: The prevalence of allergic skin test reactivity to eight common aeroallergens in the US population: results from the second $\mathrm{Na}$ tional Health and Nutrition Examination Survey. J Allergy Clin Immunol 1987;80: 669-679.

181 D’Amato G, Chatzigeorgiou G, Corsico R, Gioulekas D, Jager L, Jager S, Kontou-Fili K, Kouridakis S, Liccardi G, Meriggi A, Palma-Carlos A, Palma-Carlos ML, Pagan Aleman A, Parmiani S, Puccinelli P, Russo M, Spieksma FT, Torricelli R, Wuthrich B: Evaluation of the prevalence of skin prick test positivity to Alternaria and Cladosporium in patients with suspected respiratory allergy. A European multicenter study promoted by the Subcommittee on Aerobiology and Environmental Aspects of Inhalant Allergens of the European Academy of Allergology and Clinical Immunology. Allergy 1997;52:711-716.

-182 Nolles G, Hoekstra MO, Schouten JP, Gerritsen J, Kauffman HF: Prevalence of immunoglobulin $\mathrm{E}$ for fungi in atopic children. Clin Exp Allergy 2001;31:1564-1570.

183 Gioulekas D, Damialis A, Papakosta D, Spieksma F, Giouleka P, Patakas D: Allergenic fungi spore records (15 years) and sensitization in patients with respiratory allergy in Thessaloniki-Greece. J Investig Allergol Clin Immunol 2004;14:225-231.

184 Pumihirun P, Towiwat P, Mahakit P: Aeroallergen sensitivity of Thai patients with allergic rhinitis. Asian Pac J Allergy Immunol 1997; 15:183-185.

185 O'Neil CE, McCants ML, Salvaggio JE, Lehrer SB: Fusarium solani: prevalence of skin reactivity and antigenic allergenic analysis. J Allergy Clin Immunol 1986;77: 842-849.

186 Nordvall SL, Johansson S: IgE antibodies to Pityrosporum orbiculare in children with atopic diseases. Acta Paediatr Scand 1990; 79:343-348.

187 Shankar J, Singh BP, Gaur SN, Arora N: Recombinant glutathione-S-transferase a major allergen from Alternaria alternata for clinical use in allergy patients. Mol Immunol 2006;43:1927-1932.

188 Portnoy J, Olson I, Pacheco F, Barnes C: Affinity purification of a major Alternaria allergen using a monoclonal antibody. Ann Allergy 1990;65:109-114.

189 Weichel M, Schmid-Grendelmeier P, Fluckiger S, Breitenbach M, Blaser K, Crameri R: Nuclear transport factor 2 represents a novel cross-reactive fungal allergen. Allergy 2003;58:198-206.
190 Hong SG, Cramer RA, Lawrence CB, Pryor BM: Alt a 1 allergen homologs from Alternaria and related taxa: analysis of phylogenetic content and secondary structure. Fungal Genet Biol 2005;42:119-129.

191 Cramer RA, Lawrence CB: Cloning of a gene encoding an Alt a 1 isoallergen differentially expressed by the necrotrophic fungus Alternaria brassicicola during Arabidopsis infection. Appl Environ Microbiol 2003;69:2361-2364.

192 Chou H, Lin W, Tam MF, Wang S, Han S, Shen H: Alkaline serine proteinase is a major allergen of Aspergillus flavus, a prevalent airborne Aspergillus species in the Taipei area. Int Arch Allergy Immunol 1999; 119:282-290.

193 Yu CJ, Chiou SH, Lai WY, Chiang BL, Chow LP: Characterization of a novel allergen, a major IgE-binding protein from Aspergillus flavus, as an alkaline serine protease. Biochem Biophys Res Commun 1999;261: 669-675.

194 Stewart GA, Robinson C: The immunobiology of allergenic peptidases. Clin Exp Allergy 2003;33:3-6.

195 Hemmann S, Nikolaizik WH, Schoni MH, Blaser K, Crameri R: Differential IgE recognition of recombinant Aspergillus fumigatus allergens by cystic fibrosis patients with allergic bronchopulmonary aspergillosis or Aspergillus allergy. Eur J Immunol 1998; 28:1155-1160.

196 Arruda LK, Platts-Mills TA, Fox JW, Chapman MD: Aspergillus fumigatus allergen I, a major IgE-binding protein, is a member of the mitogillin family of cytotoxins. J Exp Med 1990;172:1529-1532.

197 Jaton-Ogay K, Paris S, Huerre M, Quadroni M, Falchetto R, Togni G, Latge JP, Monod M: Cloning and disruption of the gene encoding an extracellular metalloprotease of Aspergillus fumigatus. Mol Microbiol 1994;14:917-928.

198 Reichard U, Monod M, Ruchel R: Molecular cloning and sequencing of the gene encoding an extracellular aspartic proteinase from Aspergillus fumigatus. FEMS Microbiol Lett 1995;130:69-74.

199 Fluckiger S, Fijten H, Whitley P, Blaser K, Crameri R: Cyclophilins, a new family of cross-reactive allergens. Eur J Immunol 2002;32:10-17.

200 Crameri R: Epidemiology and molecular basis of the involvement of Aspergillus fumigatus in allergic diseases. Contrib Microbiol 1999;2:44-56.

201 Limacher A, Kloer DP, Fluckiger S, Folkers G, Crameri R, Scapozza L: The crystal structure of Aspergillus fumigatus cyclophilin reveals $3 \mathrm{D}$ domain swapping of a central element. Structure 2006;14:185195. 
-202 Jaton-Ogay K, Suter M, Crameri R, Falchetto R, Fatih A, Monod M: Nucleotide sequence of a genomic and a cDNA clone encoding an extracellular alkaline protease of Aspergillus fumigatus. FEMS Microbiol Lett 1992;71:163-168.

-203 Arruda LK, Platts-Mills TA, Longbottom JL, el-Dahr JM, Chapman MD: Aspergillus fumigatus: identification of 16,18 , and 45 $\mathrm{kd}$ antigens recognized by human IgG and IgE antibodies and murine monoclonal antibodies. J Allergy Clin Immunol 1992;89: 1166-1176.

-204 Banerjee B, Kurup VP, Greenberger PA, Johnson BD, Fink JN: Cloning and expression of Aspergillus fumigatus allergen Asp f 16 mediating both humoral and cell-mediated immunity in allergic bronchopulmonary aspergillosis (ABPA). Clin Exp Allergy 2001;31:761-770.

205 Hemmann S: Cloning, Characterization and Clinical Evaluation of Recombinant Aspergillus fumigatus Allergens; thesis, University of Zürich, 1998.

-206 Saxena S, Madan T, Muralidhar K, Sarma PU: cDNA cloning, expression and characterization of an allergenic L3 ribosomal protein of Aspergillus fumigatus. Clin Exp Immunol 2003;134:86-91.

-207 Nigam S, Ghosh PC, Sarma PU: A new glycoprotein allergen/antigen with the protease activity from Aspergillus fumigatus. Int Arch Allergy Immunol 2003;132:124-131.

-208 Calera JA, Ovejero MC, Lopez-Medrano R, Segurado M, Puente P, Leal F: Characterization of the Aspergillus nidulans aspnd1 gene demonstrates that the ASPND1 antigen, which it encodes, and several Aspergillus fumigatus immunodominant antigens belong to the same family. Infect Immun 1997;65:1335-1344.

-209 Sander I, Raulf-Heimsoth M, Siethoff C, Lohaus C, Meyer HE, Baur X: Allergy to Aspergillus-derived enzymes in the baking industry: identification of beta-xylosidase from Aspergillus niger as a new allergen (Asp n 14). J Allergy Clin Immunol 1998; 102:256-264.

-210 Shen HD, Han SH: Characterization of allergens of Penicillium and Aspergillus species. J Microbiol Immunol Infect 1998;31: 141-145.

-211 Baur X, Melching-Kollmuss S, Koops F, Strassburger K, Zober A: IgE-mediated allergy to phytase - a new animal feed additive. Allergy 2002;57:943-945.

-212 Doekes G, Kamminga N, Helwegen L, Heederik D: Occupational IgE sensitisation to phytase, a phosphatase derived from Aspergillus niger. Occup Environ Med 1999; 56:454-459.

-213 Quirce S, Fernandez-Nieto M, Escudero C, Cuesta J, de Las Heras M, Sastre J: Bronchial responsiveness to bakery-derived allergens is strongly dependent on specific skin sensitivity. Allergy 2006;61:12021208 .
214 Quirce S, Fernandez-Nieto M, Bartolome B, Bombin C, Cuevas M, Sastre J: Glucoamylase: another fungal enzyme associated with baker's asthma. Ann Allergy Asthma Immunol 2002;89:197-202.

215 Cullinan P, Cook A, Jones M, Cannon J, Fitzgerald B, Taylor AJ: Clinical responses to ingested fungal alpha-amylase and hemicellulase in persons sensitized to Aspergillus fumigatus? Allergy 1997;52:346-349.

216 Tatsumi H, Ogawa Y, Murakami S, Ishida Y, Murakami K, Masaki A, Kawabe $\mathrm{H}$, Arimura H, Nakano E, Motai H: A full length cDNA clone for the alkaline protease from Aspergillus oryzae: structural analysis and expression in Saccharomyces cerevisiae. Mol Gen Genet 1989;219:33-38.

217 Smith TA, Parker G, Hussain T: Respiratory symptoms and wheat flour exposure: a study of flour millers. Occup Med 2000;50: 25-29.

218 Biagini RE, MacKenzie BA, Sammons DL, Smith JP, Striley CA, Robertson SK, Snawder JE: Evaluation of the prevalence of antiwheat-, anti-flour dust, and anti-alphaamylase specific IgE antibodies in US blood donors. Ann Allergy Asthma Immunol 2004;92:649-653.

219 Moneo I, Alday E, Gonzalez-Munoz M, Maqueda J, Curiel G, Lucena R: $\alpha$-Amylase hypersensitivity in non-exposed millers. Occup Med (Lond) 1994;44:91-94.

-220 Tsukagoshi N, Furukawa M, Nagaba H, Kirita N, Tsuboi A, Udaka S: Isolation of a cDNA encoding Aspergillus oryzae Takaamylase A: evidence for multiple related genes. Gene 1989;84:319-327.

221 Muir DC, Verrall AB, Julian JA, Millman JM, Beaudin MA, Dolovich J: Occupational sensitization to lactase. Am J Ind Med 1997; 31:570-571.

222 Bernstein JA, Bernstein DI, Stauder T, Lummus Z, Bernstein IL: A cross-sectional survey of sensitization to Aspergillus oryzae-derived lactase in pharmaceutical workers. J Allergy Clin Immunol 1999;103: 1153-1157.

223 Binkley KE: Allergy to supplemental lactase enzyme. J Allergy Clin Immunol 1996; 97:1414-1416.

224 Lindstedt M, Schiott A, Johnsen CR, Roggen E, Johansson-Lindbom B, Borrebaeck CA: Individuals with occupational allergy to detergent enzymes display a differential transcriptional regulation and cellular immune response. Clin Exp Allergy 2005;35: 199-206.

225 Westwood GS, Huang SW, Keyhani NO Molecular and immunological characterization of allergens from the entomopathogenic fungus Beauveria bassiana. Clin Mol Allergy 2006;4:12.
226 Shen HD, Choo KB, Lee HH, Hsieh JC, Lin WL, Lee WR, Han SH: The 40-kilodalton allergen of Candida albicans is an alcohol dehydrogenase: molecular cloning and immunological analysis using monoclonal antibodies. Clin Exp Allergy 1991;21:675681.

227 Chou H, Tam MF, Chang CY, Lai HY, Huang MH, Chou CT, Lee SS, Shen HD: Characterization of a novel Candida albicans $29 \mathrm{kDa}$ IgE-binding protein - purification, cDNA isolation and heterologous expression of Cand a 3. Allergy 2003;58: 1157-1164.

228 Asako Y, Saito A, Yasueda H, Kawaguchi H, Akiyama K, Endo M, Onishi Y, Takesako K: Analysis of IgE reactivities of purified allergens from Candida albicans and Malassezia furfur among patients with atopic dermatitis (in Japanese). Arerugi 2002;51: 615-621.

229 Ito K, Ishiguro A, Kanbe T, Tanaka K, Torii S: Detection of IgE antibody against Candida albicans enolase and its crossreactivity to Saccharomyces cerevisiae enolase. Clin Exp Allergy 1995;25:522-528.

230 Mason AB, Buckley HR, Gorman JA: Molecular cloning and characterization of the Candida albicans enolase gene. J Bacteriol 1993;175:2632-2639.

231 Ishiguro A, Homma M, Torii S, Tanaka K: Identification of Candida albicans antigens reactive with immunoglobulin $\mathrm{E}$ antibody of human sera. Infect Immun 1992;60: 1550-1557.

232 al-Dughaym AM, Matthews RC, Burnie JP: Epitope mapping human heat shock protein 90 with sera from infected patients. FEMS Immunol Med Microbiol 1994;8:4348.

233 Muthuvel A, Rajamani R, Senthilvelan M, Manikandan S, Sheeladevi R: Modification of allergenicity and immunogenicity of formate dehydrogenase by conjugation with linear mono methoxy poly ethylene glycol: improvement in detoxification of formate in methanol poisoning. Clin Chim Acta 2006;374:122-128.

234 Aukrust L, Borch SM: Partial purification and characterization of two Cladosporium herbarum allergens. Int Arch Allergy Appl Immunol 1979;60:68-79.

235 Zhang L, Muradia G, Curran IH, Rode H, Vijay HM: A cDNA clone coding for a novel allergen, Cla h III, of Cladosporium herbarum identified as a ribosomal $\mathrm{P} 2$ protein. J Immunol 1995;154:710-717.

236 Kurup VP, Shen HD, Vijay H: Immunobiology of fungal allergens. Int Arch Allergy Immunol 2002;129:181-188.

-237 Falsone SF, Weichel M, Crameri R, Breitenbach M, Kungl AJ: Unfolding and doublestranded DNA binding of the cold shock protein homologue Cla h 8 from Cladosporium herbarum. J Biol Chem 2002;277: 16512-16516. 
\$238 Weichel M, Schmid-Grendelmeier P, Rhyner C, Achatz G, Blaser K, Crameri R: Immunoglobulin E-binding and skin test reactivity to hydrophobin $\mathrm{HCh}-1$ from Cladosporium herbarum, the first allergenic cell wall component of fungi. Clin Exp Allergy 2003;33:72-77.

-239 Gupta R, Sharma V, Sridhara S, Singh BP, Arora N: Identification of serine protease as a major allergen of Curvularia lunata. Allergy 2004;59:421-427.

-240 Sharma V, Gupta R, Jhingran A, Singh BP, Sridhara S, Gaur SN, Arora N: Cloning, recombinant expression and activity studies of a major allergen 'enolase' from the fungus Curvularia lunata. J Clin Immunol 2006;26:360-369.

-241 Bisht V, Arora N, Singh BP, Pasha S, Gaur SN, Sridhara S: Epi p 1, an allergenic glycoprotein of Epicoccum purpurascens is a serine protease. FEMS Immunol Med Microbiol 2004;42:205-211.

-242 Hoff M, Ballmer-Weber BK, Niggemann B, Cistero-Bahima A, San Miguel-Moncin M, Conti A, Haustein D, Vieths S: Molecular cloning and immunological characterisation of potential allergens from the mould Fusarium culmorum. Mol Immunol 2003; 39:965-975.

243 Verma J, Pasha S, Gangal SV: Purification and characterization of Fus sI3596*, a 65 kd allergen of Fusarium solani. Mol Cell Biochem 1994;131:157-166.

-244 Verma J, Singh BP, Sridhara S, Gaur SN, Arora N: Purification and characterization of a cross-reactive $45-\mathrm{kD}$ major allergen of Fusarium solani. Int Arch Allergy Immunol 2003;130:193-199.

-245 Shen HD, Lin WL, Tsai JJ, Liaw SF, Han SH: Allergenic components in three different species of Penicillium: crossreactivity among major allergens. Clin Exp Allergy 1996;26:444-451.

-246 Chou H, Chang CY, Tsai JJ, Tang RB, Lee SS, Wang SR, Peng HJ, Shen HD: The prevalence of $\operatorname{IgE}$ antibody reactivity against the alkaline serine protease major allergen of Penicillium chrysogenum increases with the age of asthmatic patients. Ann Allergy Asthma Immunol 2003;90:248-253.

-247 Shen HD, Liaw SF, Lin WL, Ro LH, Yang $\mathrm{HL}$, Han SH: Molecular cloning of cDNA coding for the $68 \mathrm{kDa}$ allergen of Penicillium notatum using MoAbs. Clin Exp Allergy 1995;25:350-356.

-248 Su NY, Yu CJ, Shen HD, Pan FM, Chow LP: Pen $c$ 1, a novel enzymic allergen protein from Penicillium citrinum. Purification, characterization, cloning and expression. Eur J Biochem 1999;261:115-123.
249 Nittner-Marszalska M, Wojcicka-Kustrzeba I, Bogacka E, Patkowski J, Dobek R: Skin prick test response to enzyme enolase of the baker's yeast (Saccharomyces cerevisiae) in diagnosis of respiratory allergy. Med Sci Monit 2001;7:121-124.

250 Holland MJ, Holland JP, Thill GP, Jackson KA: The primary structures of two yeast enolase genes. Homology between the $5^{\prime}$ noncoding flanking regions of yeast enolase and glyceraldehyde-3-phosphate dehydrogenase genes. J Biol Chem 1981;256: 1385-1395.

251 Vojdani A: Antibodies against Stachybotrys chartarum extract and its antigenic components, Stachyhemolysin and Stachyrase-A: a new clinical biomarker. Med Sci Monit 2005;11:BR139-BR145.

252 Jakobsen CG, Bodtger U, Kristensen P, Poulsen LK, Roggen EL: Isolation of highaffinity human $\operatorname{IgE}$ and $\operatorname{IgG}$ antibodies recognising Bet $\mathrm{v} 1$ and Humicola lanuginosa lipase from combinatorial phage libraries. Mol Immunol 2004;41:941-953.

253 Woodfolk JA, Wheatley LM, Piyasena RV, Benjamin DC, Platts-Mills TA: Trichophyton antigens associated with IgE antibodies and delayed type hypersensitivity. Sequence homology to two families of serine proteinases. J Biol Chem 1998;273:2948929496.

254 Deuell B, Arruda LK, Hayden ML, Chapman MD, Platts-Mills TA: Trichophyton tonsurans allergen. I. Characterization of a protein that causes immediate but not delayed hypersensitivity. J Immunol 1991;147: 96-101.

255 Zargari A, Schmidt M, Lundberg M, Scheynius A, Whitley P: Immunologic characterization of natural and recombinant Mal $\mathrm{f} 1$ yeast allergen. J Allergy Clin Immunol 1999;103:877-884.

256 Johansson C, Eshaghi H, Linder MT, Jakobson E, Scheynius A: Positive atopy patch test reaction to Malassezia furfur in atopic dermatitis correlates with a T helper 2-like peripheral blood mononuclear cells response. J Invest Dermatol 2002;118:10441051.

257 Schmidt M, Zargari A, Holt P, Lindbom L, Hellman U, Whitley P, van der Ploeg I, Harfast B, Scheynius A: The complete cDNA sequence and expression of the first major allergenic protein of Malassezia furfur, Mal f 1. Eur J Biochem 1997;246:181-185.
258 Rasool O, Zargari A, Almqvist J, Eshaghi H, Whitley P, Scheynius A: Cloning, characterization and expression of complete coding sequences of three IgE binding Malassezia furfur allergens, Mal $\mathrm{f} 7$, Mal $\mathrm{f} 8$ and Mal f 9. Eur J Biochem 2000;267:43554361.

259 Johansson C, Tengvall Linder M, Aalberse RC, Scheynius A: Elevated levels of IgG and IgG4 to Malassezia allergens in atopic eczema patients with IgE reactivity to Malassezia. Int Arch Allergy Immunol 2004;135: 93-100.

260 Casagrande BF, Fluckiger S, Linder MT, Johansson C, Scheynius A, Crameri R, Schmid-Grendelmeier P: Sensitization to the yeast Malassezia sympodialis is specific for extrinsic and intrinsic atopic eczema. J Invest Dermatol 2006;126:2414-2421.

261 Zargari A, Selander C, Rasool O, Ghanem M, Gadda G, Crameri R, Scheynius A: Mala $\mathrm{s} 12$ is a major allergen in patients with atopic eczema and has sequence similarities to the GMC oxidoreductase family. Allergy 2007;62:695-703.

262 Croce MA, da Costa Manso ER, Gambale W, Takayama L, Oliveira Andrade CE, Pereira Pinto JH, Morato Castro FF, Croce J: Sensitization to the fungus Hemileia vastatrix (coffee leaf rust). Allergy 2001;56: 684-687.

263 Barnes C, Buckley S, Pacheco F, Portnoy J: IgE-reactive proteins from Stachybotrys chartarum. Ann Allergy Asthma Immunol 2002;89:29-33

264 Mungan D, Bavbek S, Peksari V, Celik G, Gugey E, Misirligil Z: Trichophyton sensitivity in allergic and nonallergic asthma. Allergy 2001;56:558-562.

265 Green B, Blachere F, Beezhold D, Weissman D, Hogan M, Wilson N, Schmechel D: IgE reactivity to Paecilomyces variotii antigens in fungal sensitized patients. J Allergy Clin Immunol 2007;119:S187.

266 Giannini EH, Northey WT, Leathers CR: The allergenic significance of certain fungi rarely reported as allergens. Ann Allergy 1975; 35:372-376.

267 Martinez Ordaz VA, Rincon Castaneda CB, Lopez Campos C, Velasco Rodriguez VM: Cutaneous hypersensitivity in patients with bronchial asthma in La Comarca Lagunera (in Spanish). Rev Alerg Mex 1997; 44:142-145.

268 Mohovic J, Gambale W, Croce J: Cutaneous positivity in patients with respiratory allergies to 42 allergenic extracts of airborne fungi isolated in São Paulo, Brazil. Allergol Immunopathol (Madr) 1988;16: 397-402. 